\title{
「田郷虎雄日記」
}

1941 (昭和16)年7月 12月分の翻刻と解題

Tsukasa IZUMI(和泉司 : Associate Professor, Toyohashi University of Technology)

هsktmzi0918@gmail.com

(日本)豊橋技術科学大学総合教育院准教授。近現代日本語文学、文学賞研究。主著に『日本統治期台湾と帝 国の文壇〈文学懸賞〉がつくる〈日本語文学〉』(東京：ひつじ書房. 2012)、「邱永漢「濁水渓」から「香港」へ一直木 賞か潤いたものと閉ざしたもの、(『本近代文学」第90集、2014)、「殖民地の唚茶店て何を(語れるか一日本統治 期台湾の都市と若者」『アジア遊学226建築の近代文学誌」勉誠出版, 2018)など。

\section{A Reproduction of Torao Tago's Diary of July-December 1941, with Bibliographical Notes}

This paper is comprised of the reproduction of a six-month period from July to December of 1941 of the diary of Torao Tago, who became famous after his play won second place in a creative writing contest sponsored by the magazine KAIZO in 1931. The diary in total covers the six years from 1940 to 1945. On December 8 the Pacific War began, and Tago set down his thoughts about this day in the diary of this period. After December 1941 Tago came back to Tokyo from Manchuria and began writing his many novels and theatrical scripts.

Keywords Diary(日記), Manchuria(満洲国), Drama(演劇), The Pacific War (太平洋戦争), Writing Activity (執筆活動) 
本資料は、戯曲作家・小説家の田郷虎雄(1901 1950)の遺した1940(昭和15)年 から 1945(昭和20)年までの6年分の日記(以下、「田郷虎雄日記」と称す)の翻刻で ある。『跨境』第9号掲載の1941(昭和16)年1月 6月分に引き続き、1941年の後半分 を公開する。解題については、1940(昭和15)年1月 6月分が掲載されている第7号 をご参照いただきたい。

本資料は今回、「田郷虎雄日記」全体のうち、1941(昭和16)年の7月1日から 12 月31日までの半年分を翻刻したものになる。残り4年分も、順次公開を続けてい く予定である。

1941年後半は前半の6月から引き続き、満洲視察旅行中の場面から始まる。

同年5月24日から7月14日にかけて、田郷虎雄は満鉄の招聘により、「満洲」旅 行に出かけている。1939年に続き二度目の「満洲」旅行の目的は、「満洲」内の各地 域に住んでいる人々に対する慰安・慰問を目的とする「厚生船」および「厚生列車」 の取材、及びそれを通じての「満ソ北部国境」の視察であったらしい。

内地へ戻った後、1941年後半の田郷は、連載小説や依頼された戯曲脚本の執筆 などに追われている。その最中、12月8日から16日までの9日間、田郷は福田清 人(1904 1995) と共に九州へ満洲視察についての講演旅行に出かけている。この 講演旅行における田郷の演目は、常に「厚生列車・厚生船」及び「満ソ北部国境」に ついてであった。

同行者の福田清人は戦後に児童文学研究者となるが、この当時は作家として満 洲にかかわる小説テクストを執筆・発表していた。田郷虎雄とは、同じ長崎県出 身者として親しかった。戦後になって田郷が死去した後も、福田は度々田郷に言 及したテクストを発表している。

もう一点注目すべき事項は、この講演旅行出発当日に日本政府が行った対米英 宣戦布告を受けての田郷の反応である。

1941年12月8日、田郷はその日夜の夜行列車で長崎へ向からことになってお り、講演旅行出資企業である満鉄の東京支社に出向いていた。田鄉は東京支社へ 向かう途中、新橋駅前で対米英宣戦に関する新聞の号外売りを見かけている。こ の日、朝7時に日本軍が米英軍と戦闘状態に入ったとの臨時ニュースが流れてい るが、夜中に眠れなくなった田郷は朝寝をしてしまい、そのニュースを聞かな かったようである。号外売りの新聞を読んで、「非常なショック」を受けたと記 
している。

そして、東京支社に着き、福田と共に旅行の打合せをしていた田郷たちのと ころへ、11時30分から対米英宣戦布告の臨時ニュースが流机るので、満鉄東京支 社屋上に集まるようにとの社員向け告知が届く。田郷と福田も一緒に屋上へ行 き、臨時ニュースを聞くことになるのである。

田郷はこのニュースに接して緊張を露わにし感激した様子を日記に綴ってい る。12月31日の日記では、「日本が実力をもって世界史に登場した年」世界の人 に永久に記憶される」とまで書いている。この段階で、田郷の日記からは反戦的 な記述は見られない。ただ、田郷は一貫して日記では政治的な問題について触れ ておらず、私的な日記の内部とはいえ、書く内容について警戒していた可能性も ある。実際、戦争の緊張感がみなぎっていたのは12月8日当日くらいで、翌日以 降、講演旅行に出かけた田郷の日記は、故郷・長崎から九州各県を回る旅行を満 喫する様子に満ちており、戦争の影はこの時点では全くない。わずかに、燈火 管制について触れられるのみである。

前年の1940年頃から順調に仕事が入り、単行本も数々出版されるようになっ たことで、経済的な安定を得た田郷であったが、1941年は本人としては不服の 一年であったらしい。年末に、翌年からの巻き返しを誓っている。

翻刻は、以下のような凡例に従って行った。

凡例

1 原則として、漢字の旧字・俗字・異体字は通行のものに改め、旧仮名遣 いは原文のままとした。但し、本文中、旧仮名遣いで表現すべき簓所 が現代仮名遣いになっている箇所も多く、それらはそのままとした。

例1「っ」は大文字の場合と小文字の場合が混在している。

例2「〜ようだ」は旧仮名遣いでは「へうだ」となるが、本文で多くは「〜よ うだ」と表記されている。

また、人名については、旧字を用いている場合はそのままとした。

2 誤記・誤字・脱字が明白な箇所はその箇所の直後に(_) を付してその 括弧内に正確な表記を記入した。

3 句読点及び改行については、判別が難しい場合、翻刻者が適宜判断し た。また、文末で句点がない箇所については、翻刻者の判断で適宜句 点を追加した。

4 原文は縦書きであるが、本資料は横書きで表記するため、「くりかえ し」を示す各種記号の中で、横書きに適さないものは翻刻者の判断でひ らがな・カタカナに書き換えた。

5 人名、地名の羅列が行われている箇所では、適宜読点等を補った。

6 日記本文では、書籍名・雑誌名にカギ括弧がつかなかったり、省略表 
記をしていたり(例：「小学生の科学」 $ヤ$ 「小科」)、漢字をカタカナに開 いて表記したりしているが(例(「少女俱楽部」 $\rightarrow$ 「少女クラブ」)、基本的 に原文のままにした。

7 日付の前に「○」や「囚」がついている日付がある。現状、意味は不明だ が、原文のまま記載している。

8 本文中、判別が出来なかった文字は「○」で置き換えた。また、誤字等 を塗りつぶした跡と思われる箇所は「正置き換えた。

9 各月冒頭「諸事要録」欄に、月内に書いた原稿の数量と受け取った原稿 料が記載されている。この欄については、その文学史上の資料的価値 から、原文の形式より見やすさを優先することにして、各月の体裁を 統一し、作品タイトルや揭載紙誌名、出版社等の記述を分かる範囲で 正確なものに整えた。また、原文では漢数字が用いられているが、こ の項目についてはアラビア数字に置き換えた。

7月諸事要録

仕事

小説「亜細亜の柱」『子供の科学』

21 枚

ラジオドラマ「梅六成」(脚色) JOAK

23枚

児童劇「北風と白菊」『幼年俱楽部』

13.5枚

計

57.5 枚

収入

「亜細亜の柱」誠文堂より

63円

「旅費補助」大陸開拓文芸懇話会より

300円

「素人劇講座」文化中央連盟より

78円

計

441円

7月1日(火) 晴

厚生列車。

山神府一緑神(建設線)。

詳細は別記。

7月2日 (水) 啨

厚生列車。

緑神(建設線)から綏化へ回送。

詳細は別記。

7月3日 (木) 曇

厚生列車。

綏化。 
詳細は別記。

7月4日(金) 晴

厚生列車。

鉄山砲。

詳細は別記。

7月5日（土）晴

厚生列車。

鉄山砲一岩手一石長一神樹。

詳しくは別記。

7月6日 (日)

厚生列車。

神樹。

詳細別記。

7月7日(月) 雨

厚生列車。

聖浪一小白。

詳細は別記。

7月8日 (火) 晴

厚生列車。

郎鄉一帯嶺。

詳細別記。

7月9日 (水)

記載なし。

7月10日 (木)

記載なし。

7月11日(金) 晴

朝、奉天につく。

北尾氏に迎へられ、ホービル・ホテルに投宿。服を変へて、鉄道総局に出か

ける。千田氏その他に挨拶し、北尾氏に案内されて、馬鼻痕研究所訪問。

千田氏の招待で昼食。

午後、総局にて座談会。

夜も座談会。 
改造社の小林と逢ふ。

7月12日（土）晴

北尾氏一家に送られ、奉天飛行場から空路帰途につく。

京城着一天候の都合で、之より先は飛ばめことになる。当惑する。

汽車に乗る。二等は立錐の余地もないので、一等にする。

7月13日（日）晴

朝、下関着。

直ちに汽車に移る。

一等車には建川大使夫人の一行が乗ってるて寝台の都合がつかないので、夜 は一等から二等に移る。幸ひ寝台も手に入る。

飛行機で知合になった松本氏と夕食に一杯やる。

いよいよ明朝は東京だ!

(0)7月14日(月) 晴

京城で飛行機を下された時には一体どうなることはと思ひ、長い道中を思っ てウンザリしたが、つひに列車は品川駅に着いた。予定の七時十六分よりは四十 分余りの延着で午前八時…。駅に登美子、嫂、阿部さん一家が迎へに来てるた。 不思議な縁で、船中車中ずっと馴染となった松本氏と別れて、電車で家に帰る。 五月二十四日に家を出てから正に五十二日目である。

夜は兄一家、阿部さん一家、宮下氏安藤氏を迎へて夕食を共にする。

床の間には留守中に来た書面や雑誌が正に山のやうに積まれてるる。いさ> かウンザリだ・〜 。

近藤、園池、福田その他の諸氏に帰京の通知を出す。

○7月15日 (火) 曇時々小雨

昨夜は幸ひぐっすり眠れたが、しかし流石に疲労を覚え仕事をする気にはな れない。

西田君(偕成社)篠原君(誠文堂)に挨拶と原稿のことにつき書面を出し、満洲へ 世話になった人々へ出す手紙の文案を作る。田中一誠堂に印刷を頼みに行く。丸 ポの活字を持たないといふので、そこの紹介による小山の武蔵野文庫に頼みに行

く。幸ひ、明日の正午までに印刷してくれるといふので、頼んで帰る。

夜は阿部さえところから招待されてるるので一家で出かける。途中お盆なの で白木屋で花を買って行く。

阿部君のところには兄一家と宮下さんと集る。誓さんは来なかった。 
飲んで酔って例のごとく眠り、九時ごろ辞去する。

7月16日 (水) 雨、近衛第二次内閣総辞職

「亜細亜の柱」のみ切が既に過ぎてみるので今日からか〉らうと思ったが、う まく行かず、それに近藤君が果して奉天へ金を送ったかどうかも気になるので 四谷に近藤君を訪ひ、帰京の挨拶をする。奉天へは為替の関係で二百円だけ送っ てくれたさうで、残金の百円は現金で渡してくれる。ありがたい。

事務所(移住協会)へ出かける近藤君とタキシーに同乗して、満鉄東京支社を訪 ひ、近藤浩君その他に挨拶をする。

地下鉄で三越本店に行き、黒沢、山本、千田、北尾、立仙、太田の六氏に送る 浅草海苔 (二○円一○銭) と自分の開襟シャツなど買って帰る。荷物が重いので銀 座に回る勇気もない。

武蔵野文庫から礼状をとって来てさっそく自分で宛名を書き発送する。同時 に登美子に小包の荷造りをさせ、洋子と京子に送らせる。

誠文堂から三十周年のお祝ひの品が送って来る。

○7月17日 (木) 雨 大命、近衛公に再降下

今日こそと思ってるた「亜細亜の柱」をもう一日だけ怠けることにする。登美 子にビフステキをおごり、自分も昼食にビールを飲み、午睡する。入浴一夕食一 登美子たち自慢の畠に行って、少し拡張に手つだふべく草を刈り焚火をする。

夜、日記の整理、留守中の新聞の整理。

園池氏、盛会往来、西田氏、雄弁等より書簡。

7月18日 (金) 雨

便通が悪く何となく不快。

終日ゴロゴロして暮す。

$\times$

第三次近衛内閣成立。

7月19日（土）雨

「亜細亜の柱」を書く。帰京以来最初の仕事なので、調子が出ず約束の一時ま でには十枚しか書けなかったが、それだけを持って誠文堂に出かける。篠原、 田村の両君と近くの明治製菓に行ってコーヒーを飲みながら旅の話などをす る。

タキシーで偕成社に行き今村社長や西田君に挨拶をし、ついでに“ナポレオン” の打合せをする。社長から久米元一君の「成吉思汗」高垣眸君の「西郷隆盛」を苜 S。 
伊東屋により書類整理の表紙とパンチを買ひ、新橋駅前の明治製菓でコー ヒーを飲んで帰る。

夜、宮下君、先日現像と焼付を頼んだ写真(厚生列車)を持って遊びに来る。九 時頃辞去。

腹工合はまだよくないが、ビールを飲んで眠る。

7月20日(日) 雨

「亜細亜の柱」の後半を書いて速達便で送る約束であったが、どうしても気乗 りがせず、午前も午後も昼寝をして過す。長途の旅の疲れか、昼間は無暗と眠 い。

午前十一時ごろ安藤君、カバンの交換がてら遊びに来る。

おやつに「そばがき」を食べる。後入保時代を思ひ出す。

午後四時二十分、雨をついて家を出る。千㱜屋で大島、園池両氏と落合ひ同道 で銀座裏の「隠豪屋」に行く。‥両氏主催の僕の歓迎会である。元気よく旅行のみ やげ話をする。コロンバンでコーヒーを飲み、紀伊國屋で「満ソ風物誌」を買っ て帰る。

催眠剤を使って眠る。

北尾虎男氏より金百式拾五円七十三銭也の為替と書簡来る。

7月22日 (火) 雨

今夕あたり台風が襲来するさうで、ラヂオも新聞も盛に警告を発してるる。 この台風が一過すればカラリとした夏になりさうである。少々の台風は我慢す るとして、早く晴れてもらひたいものだ。この梅雨のぶり返しは全くやりきれ ない。

「梅六成」の脚色にか〉る。調子が乗らずウヤムヤで一日を過す。 夜は情報局の招待。この天気にとも思ったが、移動劇に関することなので、 思ひきって出かける。会場は山王の星ヶ岡茶寮。新橋からタキシーを飛ばす。千 賀氏上泉氏の既に来てるて、満洲の話など出る。

川面部長以下多数出席。招か九た方は田郷、大島万世、齋藤豊吉の三人。真船 君は欠席。

九時頃散会。新橋まで自動車で送ってもらひ、大した雨風にも遭はないで無 事帰宅。

西村氏(講談社) 来訪。

7月23日 (水) 晴

洋子、昨日より学校を休んでるるが幸ひ大したこともなささうだ。 
台風は予報ほどには大したものでなくの終ったが、幸ひ、予報どほり晴天に なり、俄かに暑くなった。

昨日真島氏(放送局)より速達をもらってるるので、今日は是非「梅六成」の脚色 にか>ららと思ったが、どうにも調子が出ない。

登美子は隣組で樋口のお爺さんさんをお見舞ひに出かける。

私も五反田まで散歩に出かけ、白木屋でコーヒーを飲んで電車で帰る。

電車の中で新亜細亜」を読んでるたら、旗ヶ岡を乗越してしまって長原で降 りる。

夕食にビールを飲み、十時頃から仕事にか〉る。三時頃寝る。

7月24日 (木) 晴

朝寝。朝食後他 $\mathrm{d}$ 地に仕事にか〉る。

「梅六成」の脚色である。三時過ぎには出来上りかけたが、枚数が甚だしく超 過しさうなので、金谷君に電話をかけて、明朝の九時までに届ける約束をす る。徹夜の覚悟で、夕食に酒を飲む。

宮下、安藤両氏来る。宮下君は先日依頼した写真を持って来てくれたのであ る。三人で又飲む。酒が水ツぽくて、甚だ酔心地が悪い。口直しにビールを飲 む。

両氏九時頃帰る。すぐに眠る。

朝日壮吉氏 (吉田甲子太郎氏)より著書(負けない少年)の寄贈を受ける。

7月25日(金) 晴

目が覚めたのが夜中の一時、酒が悪かったせるか、気分はよくなかったが、 もう猶予はならないので起きて仕事にか る。八月一日少国民の時間放送の棟田 博原作「梅六成」の脚色である。昨日出来る筈だったのが、枚数超過のため、やり 直しにか〉ったわけである。八時には出来上ったが、けっきょく、三枚ばかり の超過、仕様がないので、急いで朝飯をすまし自分で届けに行く。金谷君も間島 君も来てるないので受付に預けて帰る。

明治製菓(新橋)でコーヒーを飲んでもうすぐに家に帰る。

少しばかり午睡。朝日壮吉さんから送ってもらった「負けない少年」を読む。 なかなかよろしい。

入浴、何だか久しぶりのやうな気がする。

今朝来た黒沢さん(哈爾浜、十八日出)に返事一写真二枚入れて上げる。

畠で焚火。博洋堂から少女俱楽部を六冊買って来る。－黑河の太田さんに送 るため。 
夜、登美子と散歩。三浦屋でうどんを食べる。

(催眠剂を服んで眠る)

7月26日 (土）晴、夕一小雨

昨夜の催眠剤がきいてよく眠れたので子供たちと同じ位に起きる。

朝食後、児童劇(幼年俱楽部)にか〉る。ずっと前に少女の友に発表した自作の

童話「北風と白菊」のストリーを使って児童劇五場(十三枚半)にして午後一時ごろ

出来あがる。自分では案外よいやうな気がするので、さっそく京子に書留速達 で送らせる。

北村六郎君(新興キネマ)来訪。

夕食前ホンのしばらく腹こなしに畠を掘る。

西田君(偕成社)に「ナポレオン大戦回想録」黒河の太田氏に「少女俱楽部」六冊を 送る。

吉田甲子太郎氏に礼状。

$\diamond$ 日仏印共同防衛成立。

$\diamond$ 英米、日本資産を凍結す。

7月27日（日）晴

今日から「ナポレオン」にか〉る。偕成社から出す。青少年の読物だ。

渡満前に二○枚、ハルピンで百枚ばかり描いてるたのだが、すっかり始めか ら書き直すことにする。

安藤君来訪。

夕方から畠に出て開墾をやる。

篠崎氏 (童話春秋社長) 来訪。

宮下氏も来訪。

篠崎氏との間に「日本の娘」を出版の約束をする。

7月28日（月）晴

「ナポレオン」続行。

7月29日 (火) 雨

「ナポレオン」をつぶける。

夜分、永井君来訪。 
7月30日 (水) 雨

「ナポレオン」をつぶける。

山下馬之助氏夫人逝去。夜、登美子と洋子をお通夜にやる。

7月31日(木) 雨、午後晴

「ナポレオン」をつぶける。

京子を伴ひ、山下夫人の告別式に参列する。濱野、大石君等に逢子。

嫂と美知子もその帰りに寄る。

夜、私の帰京歓迎会。

エルテルで落合ひ、「樽平」外一力所

○参加者…大山、西沢、永井、川島の四君。

八月諸事要録

仕事

随筆「厚生列車厚生船」『学芸新聞』

3枚

随筆「厚生列車寸描」『国民演劇』

12枚

伝記「ナポレオン」偕成社

310枚

小説「亜細亜の柱」『子供の科学』

22枚

小説「宿営車の夫人」『令女界』

17枚

随筆「厚生列車搭乗日記」 『日本の風俗』

13.5枚

計

477枚

収入

「亜細亜の柱」『供の科学』

63円

脚本「梅六成」放送局JOAK

50円

戯曲「北風と白菊」『幼年俱楽部』

33.75円

計

146.75円

8月1日(金) 晴

「ナポレオン」をつぶける。

宮下君来訪。

8月2日（土）晴

「ナポレオン」をつぶける。

学芸新聞より速達一原稿の催促。

8月3日（日）晴、夕立

「ナポレオン」をつぶける。

午前中、西村氏 (幼年俱楽部) 来訪。 
「北風と白ぎ等くの件…傑作だと言って挿絵の打合せをし、喜んで帰る。

图、兄の家に招ばれてゆく。安藤君と同伴。篠つくやうな夕立の中を出かけ る。

8月4日(月) 晴

「厚生船、厚生列車」の原稿を書き霞が関ビルの「学芸新聞社」に持参。誰もる ないので原稿をおいて帰る。

本日「ナポレオン」の第三篇「希望の日」を終る。

8月5日（火）晴

「厚生列車寸描」(一二枚)脱稿。「国民演劇」に速達で送る。

小嶺嘉太郎君来訪…愛国婦人に勤める傍ら古本屋を始めたといふ。

8月6日 (水) 晴

「ナポレオン」をつぶける。

栄光の日 二十一枚 $(1 \cdot 2 \cdot 3)$

西田君(偕成社)松久君(令女界)より速達。

哈爾浜。黒沢、秩父両氏より手紙。

秩父君からは写真も同封して来る。

8月7日 (木) 晴

「ナポレオン」

栄光の日一九枚 $(4 \cdot 5)$

奉天の北尾氏より手紙と認印送り来る。

宮下氏来訪。下宿の件につき同道で兄の家を訪ふ。ビールを飲んで帰る。

8月8日 (金) 晴

「ナポレオン」今月に入って本日はじめて成績不良。つひにペンを投げる。

上泉氏(翼賛会文化部) より招きの葉書一午前中に出かける。思ひかけなく国民 文学の小説(時代物)の執筆を頼まれる。

条件も甚だよいし、意義も大いにあることだし、且つ又、上泉さんが中に 入っての仕事なので、むしろ、大いに感謝して引受ける。

兄一家来訪。夕飯を共にする。

8月9日（土）曇、夕方雨

「ナポレオン」「栄光の日」を完成。

佐世保の父より手紙(金五円在中)

幼年俱楽部より稿料送り来る。京子をつれて丸内三和にとりに行く。 
西田君より速達。

宮下君来訪。

夜、隣組常会。

8月10日(日) 雨

「ナポレオン」は「栄光の日」の整理。

午後、神崎清君来訪。かなり長く話しこんで行く。

宮下一家来訪。…今朝新橋着。洋子京子迎へに行ったが、行違ひになって逢 へずにみたのである。

8月11日(月) 量、小雨

今日は又仕事の成績不良。「ナポレオン」も駄目「亜細亜の柱」も駄目。

宮下一家○引揚げる。

夜はこの町会だけの燈火管制。

8月12日(火) 曾

「亜細亜の柱」(二二枚)完成。速達で送る。

篠崎氏 (童話春秋社)より原稿受領の旨の手紙来る。

燈火管制。

令女界のプラン(小説)を練る。

夕方、上原氏児童劇の原稿をもって来訪。著書の寄贈を受ける。

8月13日 (水)

「ナポレオン」をつぶける。

「運命の日」に着手。

放送局より八月一日放送の著作権料送り来る。

洋子腹痛にて山田さんに来てもらふ。大腸カタルとのこと。

道彌、善道の両君来り、畠の開墾をやって帰る。

8月14日(木) 量り、夕方、雨

「ナポレオン」をつがける。

夕食に酒を用ひ、少しく寝て夜もつがける。

8月15日 (金) 雨、後、曇

「ナポレオン」をつぶける。

夜も夕食に酒を用ひ少しく寝て続行。 
○8月16日（土）晴

今日は「ナポレオン」を完成して西田君に渡す約束の日。早朝から着手して午 後三時、全三一○枚を終る。

西田君(偕成社)原稿を受取りに来る。喜んで帰る。

夜は返事を怠ってるた満洲の人々へ手紙を書く。重荷を下したやうな気がす る。

藤崎二男君来訪。

宮下一家来訪。

8月17日(日) 晴

令女界の小説にか>るつもりだったが駄目だったので、洋子京子とつれて家 を出る。宮下君の下宿に寄り、美知子も誘はせて、萩子君道彌君をも加へ銀座に 出かける。

美松地下で昼食の後、日本劇場に入る。アトラクションと「雪子と夏代」。

帰途、資生堂でアイスクリームを食べ、新橋の地下鉄ストアで小鳥焼を買っ て帰る。

安藤君が来てるる。一杯飲む。泊って帰る。

8月18日（月）晴

午前十一時、改造社の小林君と「大陸」に書く原稿のことでジャーマンベーカ

リーに落合ふ約束なので出かける。

小林君は来ないで「大陸」の富重君が来る。一時間余り話して別れる。

西田君(偕成社)に「ナポレオン」の年表を送る。

この留守の間に西沢君が「日本の風俗」の編集者とともに写真を借りに来たと のこと。

夜は文芸会館の「国民演劇の会」に出かける。

散会後、大島、小林宗吾、渋田の諸君とアイスクリームを食べて別れる。

安藤君、京子をつれて井頭公園に遊びに行く。

8月19日 (火) 晴

令女界の小説に着手。成績不良。

夕食後しばらく寝て、再び仕事にか〉る。これも不良。

8月20日 (水) 晴

「宿営車の夫人」五、六枚書いて投げ出す。

午睡。

夕方、身のおきどころもない気持で、一家で阿部君宅を訪ふ。 
ビールとウキスキーを御馳走になって帰る。

川島、西沢、岡田の三氏に手紙。

8月21日 (木) 啨

「宿営車の夫人」一七枚午前中に脱稿、自分で宝文館に持参。

北村氏に渡して神保町に出かける。「改造」(一四. 二)を探すためなり。森田屋 で求める。銀座に回り、久しぶりに更科により、コロンバンでコーヒーを飲ん で帰る。

コロンバンのコーヒーも昨日から十銭になったとのこと。

夜、一家で荏原劇場に出かける。

8月22日 (金) 晴

「ナポレオン」のあとがきか、日本の風俗の随筆を書くつもりであったが駄 目。

丸山義二君の「大陸の村つくり」を読む。

夜、阿部君一家を招く。

おそくなって宮下一家も来る。

○8月23日（土）晴

「ナポレオン」のあどかきも「日本の風俗」も駄目。

京子をつれて洗足池に行き、一時間ばかりピンポンをして帰る。

「日本の風俗」の吉岡君来訪。満洲の写真二○枚貸す。

夜、兄の家に出かける。一宮下一家を招待。

8月24日（日）晴

小説「宿営車の夫人」の後、すっかりスランプに落ちてしまった形…が、日 本の風俗の満洲みやげを書きかけてみて、どうやら明日は出来さうな気がして 来る。

ホンのちょっと午睡の後、「満洲国境問題」を買ふつもりで本屋に出かける。 第四日曜で定休日。帰って「東亜民族結合と外国勢力」を読む。

○○どうもこのごろの不信の原因の一つが運動不足にあるやうな気がする ので、久しぶりに庭いぢりをする。沈丁花を移植し、薔薇の根に肥料をやる。 農園の開墾を洋子を相手にやる。たしかに運動不足のせるもあるに違ひな い。かうして働いた後は大変気持がよい。

夜、安藤君来訪。泊って行く。

登美子は隣組の会合で和田さんちに行く。 
8月25日（月）晴

「日本の風俗」のために「厚生列車添乗日記抄」を書く。一時すぎ脱稿。洋子に速 達で送らせる。

そのあと疲れてしまって、読者もうまく進まない。思ひきって昨日のつ心゙き の開墾を洋子と二人でやる。なかなか壮快ではあったが、両手に忽ち、十二三の 豆も出来る。

会後、荏原町の本屋に行き「東亜新書」二冊買って来る。お供に来た洋子と京子 は縁日へ行くと言って出かける。

8月26日（火）晴

いよいよ今日から「大陸」の原稿に着手の予定だが、朝から何となく疲れて手 がつけられない。「満洲国境問題」を読む。

洋子に今夜の会に使ふ「アムール沿岸の地図」を書かせる。

入浴、夕食、出かける。

大陸開拓文藝秘話会臨時総会。午後六時から日比谷三信ビル八階、東洋軒に て。

8月27日 (水) 曇

「静かなる黒竜江」(大陸)にか〉る。大体出来るといふ自信をつけただけで疲 れてしまふ。

午後、一家で日劇に行く。地下室で、さんざんまたされて、すっかりイヤに なる。しかし、映画(女学生記)そのものは相当に面白かった。

○8月28日(木) 晴

（冒頭に8月27日分の日記の誤記があり、塗りつぶされている）

宮下一家来訪。道弥君に畠の手入れを頼む。

夜、宮下夫妻の御馳走で、モナミやコロンバンで食事やお茶を飲み、東宝名 人会を見る。

エビスビヤホールーモナミーコロンバンー数寄屋橋のすしー東宝名人会一エ ビスビヤホール

防空演習

○8月29日 (金) 晴

萩子さん達、今日の桜で帰る。

開拓工業協会より原稿依頼あり。 
夜、心臓が苦しくなり登美子を起す。

8月30日（土）晴

「静かなる黒竜江」やっと書けさうになるが、昨夜来の心臓が気になるので大 事をとり中止。

富重(大陸)西田(偕成社)千賀(情報局)にそれぞれぬ切延期依頼の速達を出す。

8月31日(日) 雨

「静かなる黒竜江」を書きかけたが調子面白からず。つひに挑戦的な気持で酒 を少々ながら飲んで昼寝、午後から再び執筆。どうやら今度は物になりさうに 思へるが、胸が苦しいので止す。

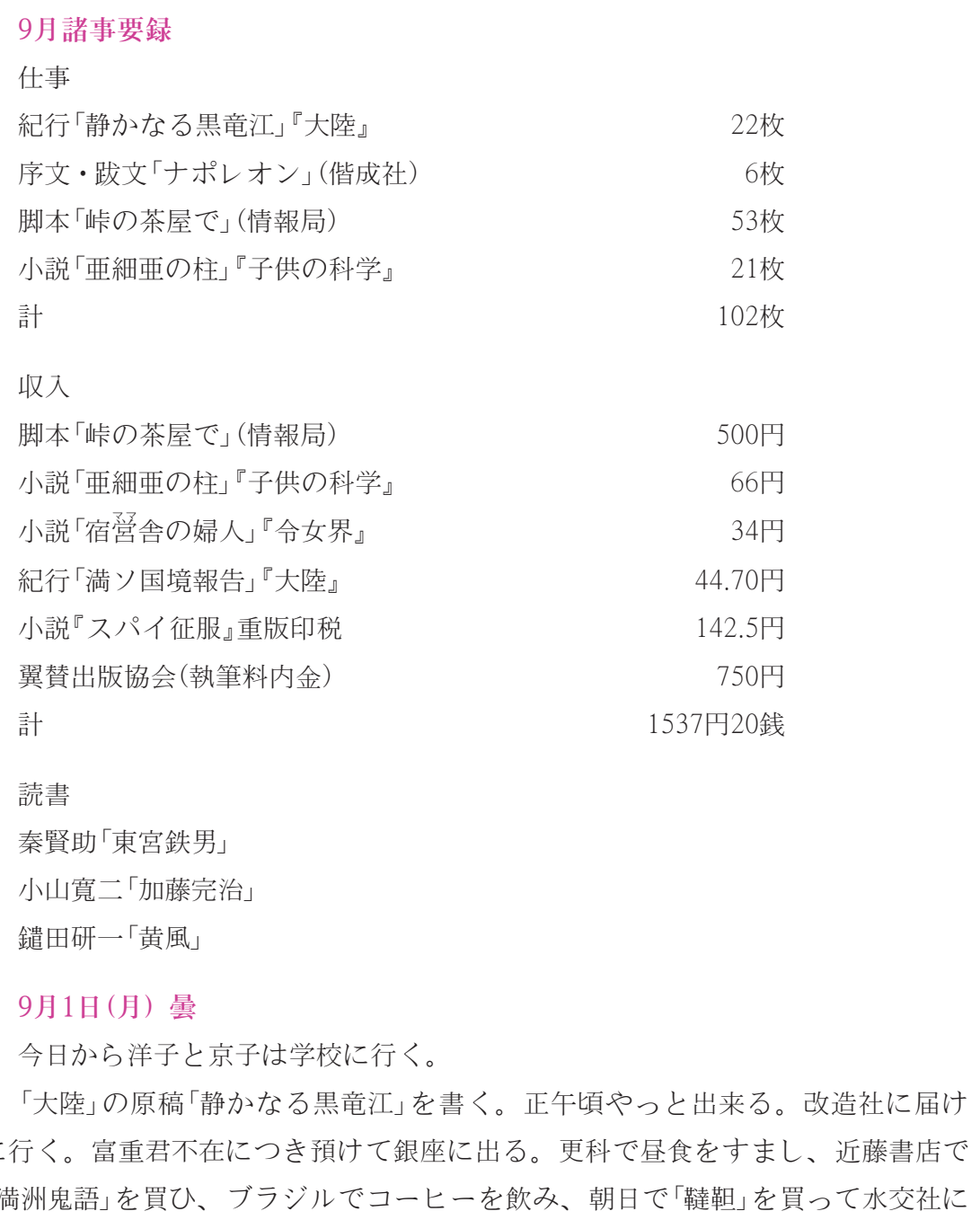


出かける。海洋少年文学の軍との懇談会。(少年文学、輝く会、博文館)古橋中佐 の話は非常に面白かった。

帰途、上沢、神崎の諸君とお茶を飲みながら語る。

9月2日(火) 晴

先月から渋ってあたナポレオンの序文とあとがきにか〉る。なかなか思はし く出来ぬ。が、やっと十二時までか〉つて書き上げ偕成社に散歩がてら持参す る。西田君不在。更科でそばを食べ、紀伊國屋を咞き、明治製菓でお茶を飲んで 帰る。帰ってみると家の前に自転車があるので、みると福田清人君である。一本 つけて喋る。九州講演(満鉄)旅行を一緒にやること、大陸文学でシリーズ(東巠 新書)を出すことなど語りあふ。五時頃㷌る。

夕食後、畠に出て草の根を燒く。

吉田甲子太郎、園池、大山の諸氏に手紙を書く。

9月3日(水) 晴

やっとやっと情報局の戯曲にとりか〉るところまで漕ぎつけた。が、テーマ もストーリーも全然準備がないので終日「国民演劇」の脚本を読んだり、新聞の切 抜をひっくりかへしたりしてみる。

午後四時頃から畠に出て京子を相手に焚火をしたり、少しばかり開墾をした りする。が、ひどく疲れたので中止して、風呂に行く。

夜もテーマを考へる。

9月4日 (木) 晴

吉田甲子太郎氏から葉書。六日の小集会のこと。で、神崎清君の家に出かけ その打合せをする。

帰って、情報局の脚本のテーマを考へる。まだ決定せぬ。それに生憎なこと に心臓の工合も少し悪い。

午睡。散歩。畠。夕食。入浴。

9月5日(金) 晴

数日泊ってみた宮下君、今日から下宿に帰る。

今日も書けぬ。(情報局の仕事)

「スパイ征服」重版（九五○）検印。

「ナポレオン」の校正。

キネマに逃避。

心蔵の方は大したこともなささうになる。 
9月6日（土）晴

午後四時、家を出て朝日新聞社を訪ふ。神崎清君と落合ひ、同道で、大森に吉 田甲子太郎氏を訪ふ。三人で大森○で夜おそくまで飲む。

この留守中に兄一家が来てるた。

9月7日(日) 晴

書けぬ。書けぬ。

宮下、安藤両氏来訪。畠の手入れをしてもらひ、夕食の時三人で飲む。

けっきょく、今日の仕事はナポレオンの校正をしただけ。

9月8日(月) 量

情報局の仕事、今日も出来ぬ。オウオウ愉しまず。

兄より速達。金のこと、その返事を聞きに美知子来る。スパイ征服の印税到 着次第それを回すことにする。

「ナポレオン」の校正。

「スパイ征服」の企画届を書く。

9月9日 (火) 量

「スパイ征服」の企画届を誠文堂へ登美子に持参させる。

北村六郎君遊びに来る。

兄に電話(誠文堂よりの印税未着のため)——美知子来る。

$\times$

園池氏より速達。…情報局の戯曲の進行状態問合せ。

大政翼賛会文化部長より速達。先般、上泉氏より交渉のあった翼賛出版協会の 顔合せ案内。

右それぞれ返事する。

9月10日 (水) 雨

完全にスランプだ!

情報局の仕事(戯曲)今日も全然書けぬ。

キネマ(渋谷一䇫)へ逃避。

千賀氏よりも進行状態問合せの葉書あり。十二日に訪問する旨の速達を出 す。

寝がてに“するめ”を看にビール一本を飲んで寝たためか夜に腹痛で困る。

9月11日(木) 雨

腹痛で一日ごろごろしてるる。

今日は午後から磐田芳枝君が北村君に案内されて遊びに来る筈だったが、撮 
影の都合で来られぬ旨——北村君ことはりに来る。

姉来る。園池氏から頼まれてるた傘持参。

(※以降の空欄に、翌9月12日の補遺が書かれている。)

9月12日 (金) 雨

園池氏を訪問。脚本が書けないことについて相談する。

今日午後一時の汽車で松江(素人劇コンクール審査)へ旅行する同氏が支度をす

る○間の時間を利用して慶應病院に樋口氏(隣人)を見舞ふ。

園池氏宅に引返し、同道で情報局(五部二課)に千賀氏を訪ひ、けっきょく十六 日まで待ってもらふことにする。

園池氏と日比谷(森永)でお茶を飲み、同氏は東京駅へ、私は常盤へ行く。

翼賛出版協会の会。

文化部長 岸田国土氏

出版協会 西川代議士

作家 福田、田郷、岩倉政治、浅野晃

一以下 九月十一日の闌へ

九月十二日の補遺

右の会の席上で、出版契約書をとり交し、執筆料の内金七百五十円をもら ふ。

散会後、コロンバンで福田君とお茶を飲み、少し本を買って帰る。

電話をかけて姉に来てもらひ、金百円也を立替へる。

「ナポレオン」再校。

9月13日（土）晴

情報局の脚本。素材を得るために感激美談集を読むことを思ひ立ち、神田金 星堂に自分で買ひに行き、十二冊ぶら下げて帰る。

帰って登美子と手分けして読む。

安藤、宮下両氏来訪。

「ナポレオン」の校正。

9月14日（日）亶

昨夜泊った安藤君は、厚生船のポスターを写真にとり、当直だからとて朝の うちに帰る。

「ナポレオン」の校正は安藤君に速達を頼む。

昨日にひきつぶき感激美談集の中にネタを探す。なかなか思はしいものもな い。

宮下君来訪。登美子と三人で荏原劇場に行き、「母なき家の母」なる大衆映画を 
見る。こ〉にもヒントを得ようと思って来たのだが、何等得るところなし。宮 下君お茶を飲んで帰る。

「スパイ征服」重版の印税 ( ・ ? . ・ . 送り来る。

9月15日(月) 雨

登美子に「スパイ征服」重版印税を受取らせ、貯金する。

情報局の仕事、今日も出来ぬ。

スランプもからなると全く苦しい。

夕方、宮下君㧍酒をもって来る。九時頃二人で飲む。

9月16日(火) 曇、後、雨

情報局の仕事(移動劇脚本)やうやく案なる。感激美談集の中にあった兵隊婆さ んにヒントを得て、創作することにする。

午後一時から登美子は常会に出席。

9月17日 (水) 雨

終日移動演劇脚本「峠の茶屋で」を書く。

今日中に持参の約束であったが、どうしても明日まではか>るので、その旨 の電報を千賀氏(情報局)に打つ。

夕食に酒を飲んで眠り、夜も書く。

今日「桜雲」に会ヒ五円送る。

9月18日 (木) 雨

「峠の茶屋で」正午近くに完成。早速情報局に持参する。千賀氏は軍の公用で不 在だったが、清島長利、萩原良太郎の両氏に逢ひ渡す。両君ともその場で読んで 大いに喜ぶ。

しかし、余り急いで書いたもので、自分としては幾多の不満があるので二日 間だけ預って帰り、手を入机ることにする。

清島君は平戸中学で図画の教師であった清島先生の令息なる由。ともにその 奇遇を喜ぶ。

日比谷書房と三昧堂で本を買って帰る。

執筆中に上澤氏、海洋少年文学の件につき来訪。

速達三通来る。

偕成社、誠文堂、藤浦洸氏。

9月19日(金) 雨

終日「峠の茶屋で」の推敲。浄書。 
右のため水交社の会(海洋少年文学の打合せ)にも欠席することにし、上澤氏に その旨ことはりに行き、藤浦君の伝言を頼む。

\section{9月20日（土）晴}

「峠の茶屋で」今朝速達で送る約束だったが、二十二日の朝まで猶予を求むる 旨の速達を清島君に速達を出し、「亜細亜の柱」にか>る。苦しいこと、苦しいこ と、こんなに書くのが苦しかったことはない。が、なんとかかんとか、でっち 上げて午後四時ごろ洋子に持参させる。

宮下、安藤両君来り、一杯やる。

宮下君も酒を持参する。

9月21日(日) 啨

終日「峠の茶屋で」の浄書。

夕方、安藤君宮下君が畠の手入れをしてるるので、休悡のつもりで、そこへ 行ってみたが、一旦調子が出ると頭の中は「峠の茶屋で」に出る人々の生活で一杯 になり、つぎからつぎとセリフが出て来る。

入浴。夕食の時、両君と酒を飲んだが、私はすぐに寝につき一時少し前に起 きる。登美子を起して茶の用意をさせ、それより早速「峠の茶屋で」にか〉り、 朝まで訂正して浄書をする。

○9月22日(月) 晴

移動演劇脚本「峠の茶屋で」一幕五十三枚、朝六時すぎ、つひに完成!

朝食後、自分で情報局に持参し、受付に預ける。

この脚本そのものに要した日数は、第一稿第二稿全部で五日間に過ぎなかっ たが、この案を得るに至るまでの十三日間は全く地獄の苦しみであった。これ ほどひどかったことは、ほんとに始予てだ。

だが、やっとすんだ!

新橋駅前の明治製菓でお茶を飲んで帰る。

午後、美枝さんと香世子ちやんが遊びに来たので、香世子ちやんをつれて八 幡さまや太平堂に出かける。

夜、阿部君も呼んで十二時まで飲む。

「令女界」並びにその稿料来る。

9月23日(火) 啨

秋季皇霊祭だ。そして我が家では母の存命中から仏事(お盆)を営むことに なってるる。が、それは午後から兄の家に出かけて行ふとして午前中は、すぐ にも「亜細亜の柱」の完結編にとりか〉らうかとも思ったが、なにしろ情報局の 
仕事でさんだん瘦せる思ひをした後なので、身が入らない。そこで誠文堂主催 の模型展覧会に顔を出すことにし、幾年ぶりにセルの袴をつけて出かける。篠 原君、田村君にも逢ひ、お茶を飲み、七回の書籍部(日本橋三越)で「概観維新史」 を買って、その足で兄の家に行く。

法要の酒を飲み、子供等の余興を見て、帰りに阿部君宅に寄りステッキをも らって帰る。

大阪放送局より「黄風」脚色の依頼。

ナポレオンの校正と企画届。

9月24日 (水) 曇、後、雨

朝、自分で本局へ「ナポレオン」の校正と企画届を速達しに行く。

「亜細亜の柱」にか〉らうかと思ったが、まる一日だけ休まうと思ひ、秦賢助 の「東宮鉄男」を読み了り、小山寬二の「加藤完治」を読む。

平戸より先日金を送って頼んで拈いた干物類が送って来る。そのことで ちょっと登美子と争ふ。

病気で弱ってるるクロべエを、つひに意を決して安らかに生を終らせること にし、獣医を呼ぶ。

夕刻、洋子に手つだはせながら、庭の一隅に墓を掘り、そこに萩の花や芙蓉 の花などをかむせ、水もそへて埋める。クロべエよ、安らかに眠れ、そして来 生はもっと元気な猫となって生れ来よ!

本日よりナポレオンの責任校了(五校)にか〉る。

9月25日 (木) 雨、後、晴

朝、雨の中を自分で本局へ「ナポレオン」の五校と出版届を速達しに行く。帰 途「偉大な王」を買ふ。

「亜細亜の柱」にか>る。完結編の緒がついたので一枚で止し、満洲紀行の準 備にか〉る。

昼食後、散歩。洗足駅付近の本屋で“国民演劇”八月号 (黒沢氏に送るため) と菊 池寛の大衆明治史上巻を買って帰る。

夜、偕成社より速達。検印用紙七千枚送り来る。

園池氏より三人会の通知。

夜、隣組の防空演習…登美子出席。

酒を少し飲んで眠る。

9月26日(金) 啨

「亜細亜の柱」完結編を三、四枚書いて、あと栗原紡織の「勤労者の作った演劇」 
を読む。

昼食にビール半本飲んで眠る。

午後、長原を散歩。世界童話劇(上下)を買って帰る。

夜、隣組の防空演習。

偕成社に検印七千部書留速達で送る。

9月27日（土）啨

「亜細亜の柱」完結編を書きかけたが、すぐに止し、「ナポレオン」前半の責任 校了の分を校正して、それを偕成社に持参する。折よく西田君もるて、近くの喫 茶店に出かける。西田君は「ナポレオン」を最後のおきみやげに山海堂の「機械化」 編集主任にそは录て転ずる由。

丸善に行き、三越(本店)で「蘭印の演劇概観」を求めた後、六回講堂に於ける誠 文堂主催の講演会を聞く。

西原勝陸軍少佐と竹岡海軍少将の講演。特に後者が面白かった。

銀座に出、コロンバンで園池、大島の両氏と落合ひ、前回同様「いんかう」で 三人会。その後うちつれて産組会館に於ける日本文化中央連盟の文化映画試写会 に行く。

「素人演劇講座」今日出来。

9月28日（日）晴

「亜細亜の柱」をホンの少し書いて今日は急けることにする。

宮下君来訪。

夕食に一杯やり、夜、ラヂオを聞きながらまた一杯やって宮下さん帰る。

安藤君はつひに来なかった。

9月29日（月）晴

「亜細亜の柱」完結編を三枚ばかり清書して明日完成の見とほしがついたので 止し、大阪放送局の依頼によるラヂオ小説脚色のため鑓田研一の「黄風」を読む。 前半の煩はしさに比べて後半は多少面白い。何とかなりさうだ。

昼食後、荏原町まで散歩し、古志太郎「佐藤信㴊」を買って来る。

多少風邪気味で午睡三時間近くもやる。

松茸飯に焼松茸…酒をグラスに三杯飲む。

夜、隣組の防空訓練。登美子が出る。

9月30日 (火) 雨

又しても雨!全く、よく降ることだ。 
情報局と誠文堂より稿料。登美子にも区よりの慰労金下付の通知来る。

「亜細亜の柱」の浄書にか>る。半分にて中止。あとは明日だ。

平戸(久田)より先日頼んでやった干物などの残りの分送り来る。かますの干 物が入ってるたので昼食に早速食べてみる。

午後、西沢君、社の少年をつれて立ち夜寄る。

冨美枝に手紙を出す。

夜は隣組の防空訓練。登美子が出る。

10月諸事要録

仕事

小説「亜細亜の柱」完結編『子供の科学』２5枚

ラヂオ小説「黄風」(脚色) JOAK 50枚

（小説「亜細亜の柱」改訂(出版のため) 140枚

計

75 枚

収入

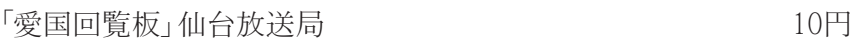

計

10円

10月1日(水）雨、夜は台風

朝、八幡様にお参りする。

「亜細亜の柱」(完結編)を書く。あと三、四枚のところで疲れて中止。

登美子、情報局の為替をとりに行く。

嫂来訪。先日立替へた百円を持って来たわけ。

雨の中に萑原町の本屋に行き、「ヒリッピン史」と「頼山陽」を○○買って来 る。

夕食後、洋子と昭栄座に「秀子の車掌さん」「三太のラッパ」を見に行く。後者 は児童映画だが非常に面白い。

帰宅すると、間もなく大嵐となる。九州を襲った台風の名残であらうか。

西田君より手紙。返事を出す。

10月2日(木) 晴

「亜細亜の柱」昨日の分は気に加汿めので始から書直す。今日も亦あと三、四 枚のところで疲れて中止。

満洲移住協会に阿部君を訪ひ、実演用の脚本を頼まれる。

産業組会会館に於ける「人形芝居愁談会」に出席。

南壮二郎、園池公功、田郷、大島万世、三林、島、農建の人久。 
散会後、東日会堂でお茶を飲み、更に三人会で旅行の打合せをする。

丸善に行く。目的にして来た維新史はもう売切れてるる。菊池寛の「大衆維新 史」と自分の「螟蛉子」を買ひ、高島屋で戦闘帽を買って帰る。

夜、登美子と京子、昭栄座に出かける。

10月3日 (金) 晴

朝、一昨夜の大嵐でやられた木の枝を焚く。焚火は私の趣味かな?

八時から一時まで「亜細亜の柱」つひに完結編二十五枚を完成する。第一回を始 めてから正に一年半つぶけて来たわけだ。自分で速達を出しにゆく。

その後は、和田さんからもらった南天の木を植急たり、今朝の残りの焚火を やったり、裏のしその穂を積んだりして過ごす。

登美子は区の慰労金を受取りに学校へ行き、正午前に帰って来たが、そのお 祝ひとて夜はウドンとソバをとり、一本つける。

夕食が終ったから、宮下君と安藤君が来、新たに飯を炊いてやり、安藤君持 参のビールを飲む。

10月4日（土）晴

大阪放送局から頼まれてるる「黄風」の脚色を今日から始めるつもりで、再読 を始める。

十一時ごろ家を出る。新橋郵便局から篠原君に速達を出し、紀伊國屋で「東印 度の文化」を買ひ、不二沙ルルで昼食をすまして日比谷公会堂に行く。くろかね 会の結成式である。

海軍大臣、聥信大臣の祝辞代読、馬㴊陸軍報道部長の祝辞、第一回くろかね賞 (南海封鎤)の授賞式。菊池寛氏の講演等で式を終り、催しものに移る。藤原義 壮、中村湖子の独唱、花柳寿輔の踊…

この会で濱野修、上林暁、近藤春雄、金谷完治、西沢揚太郎の諸君に逢ふ。泉 本三樹君とレインボーグリルでお茶をのみ、別れて水交社に三光会に出席。

五分間演説をやらされる。

篠崎仙司氏に手紙を出す。

篠原雅之君に速達。

10月5日（日）晴

すばらしいお天気だが、少し蒸暑い。

脚色のため「黄風」を読む。

京子と荏原劇場に「愛の一家」を見にゆく。非常に面白い。すっかり感心して 二度くりかへして見る。

宮下君来訪。 
今日は十五夜の月見で、且つ、登美子の誕生日だ。兄の一家も来て、さ>や かに祝宴を張る。但、兄は痔が悪いため酒は私と宮下君だけで飲む。

九時少し前みんな帰る。登美子と旗ヶ岡まで送ってゆく。

安藤君からは手紙と写真が送って来たが、本人はとうとう来なかった。

10月6日（月）晴

「黄風」の再読を終り、構想を練る。

午前中はそれだけで終り、昼食後午睡。自由ヶ丘散歩等で今日は終る。

10月7日 (火) 朝は雨、啨

ラヂオ小説「黄風」(脚色)十二、三枚で中止。

10月8日 (水) 晴

明日は三人会の旅行だから、「黄風」を是非今日中に完成したいと思ったが、 どうにも気乗りせず、午前中に十二、三枚書いただけで中止。午後、木崎好高氏 の「頼山陽」を読んでるると、園池氏より速達。病気(イケイレン)につき旅行を一 月ほど延ばしてくれとのこと。却ってホッとする。

夜、翼賛出版協会の小説の準備のつもりで萑原劇場に「碑」を見にゆく。登美 子同伴。大変面白い。

酒一合余り飲んで眠る。

○10月10日 (金) 晴

ラヂオ小説「黄風」又久、最初から書直し。やっと軌道に乗る。但、午前中で 中止。

午後は「頼山陽」や「吉田松陰」を読む。

夜、吉田松陰に関する書物を物色すべき銀座に出る。三昧堂、紀伊國屋を瞀 き、近藤書店で「吉田松陰の遊歴」を買って帰りかけてるると、千疋屋の前でぱっ たりと中野実に逢ふ。打連れて西銀座の、とあるバーに行き、林弘高氏をも加へ て国民演劇運動についての話をする。

ジのャポンに場所を移し、更に林氏の姉さんが経営する上野の店に移り十一 時半まで語る。多いまでは電車があったが、それからはなく、とうとう家まで 歩いて帰る。ずっと一匹の犬がついて来て弱った。

隣組常会に登美子出席。

10月11日（土）晴

素晴らしい秋晴だ。

登美子、今日も亦庭先に蒲団を並べつらねる。 
「黄風」五十枚つひに完成。一午前、午後、夜とつぶけて書く。

BKの山田氏から「ゲンコウイツイタダケルヤ」との電報。明朝送る旨の返電。 嫂来訪。夕刻には美枝さん母子来訪。

伝洋堂(下の古本屋)から改造社の日本地理大系を売りつけられて買ふ。

阿部君、文展に今年もうまく行かなかったらしい。但、元気で今日から銀座 (紀伊國屋)で個展を始める由。

夕方は例によって焚火。

10月12日(日) 晴

快晴。

庭で焚火。散歩がてら「黄風」の原稿を速達で送るべく自分で本局へ出かけ る。帰りに吉田松陰に関する二著と「東洋戦争実記」の合本二冊を買って帰る。

いよいよ明日から満洲紀行にか〉るべく久しぶりに机のまはりを整理する。

こ>十四、五日間、環境を満洲一色にするため。ついでに押入れの整理もやる。

午後までか〉る。

子供等は弁当持参で写生に出かけたので登美子と二人で昼食。鮙がなかなか おいしい。

宮下君来訪。

宮城県の内海捷次郎さん来訪。おみやげにモチゴメと小豆を戴く。こちらは 平戸の鮙のサーデンを上げる。

嫂来る。一美知子は洋子たちと一緒に写生に行き、先に来る。

移動劇脚本「峠の茶屋で」のプリント送り来る。

10月13日(月) 量

満洲紀行(仮題)第一日。

準備・満洲観光(雑誌)索引を拵へる。

今日は右だけで打切り、午前中に家を出る。紀伊國屋書店に阿部君たちの個展 (斥上会)を見る。

自著「ナポレオン」が、出来てるたので一冊求めて、邦楽座に行く。十二時少 し前だのに見物が列を作ってるるので、スエヒロで昼食をすまして後、右に行 く。映画「雨ぞ降る」を見るためであり。

近藤書店で春山行雄君の“満洲風物誌”を買ひ、再び紀伊國屋の斥上会に顔を出 す。阿部君もるて、長崎の頃の一級上級生であった佐田武人君を紹介してくれ る。資生堂で小村雪岱の挿絵展を見て帰る。 
留守中に西村俊成氏が来たとのこと。さっそく手紙を書く。

(※以下は日記帳上段、1940(昭和15)年10月13日の空闌部分に書かれている)

宮下君が酒をもって来ると言ってみたので、用意をして待ったが来ないの

で、ひとりで少しばかり晚酌をやる。

○10月14日 (火) 曾、午後は小雨

満洲紀行(仮題)第二日。

満ソ黒境に関する新聞の切抜だけにて今日は打切り。

園池、近藤(九州講演旅行の件)、篠原(亜細亜の柱出版の件)上り手紙来る。

園池、近藤両君に返事を書き、ついでに阿部欽一君、鑓田研一君 (黄風脚色の

件)に手紙を書く。

午前十一時半より水交社にて海軍との懇談会(少年文学の会)。

近藤書店にて「満洲通史」「満ソ国境紛争史」を求め、大崎広小路で「佐久間象山」 (岩波版)を求めて帰る。

宮下君、酒一升さげてやって来る。

10月15日 (水) 晴

満洲紀行(仮題)第三日。

今日からいよいよペンをおろすつもりで、朝の焚火もなにも止めて食後まも なく机についたが、やはり書出しは、さうかんたん浔は行かめ。けっきょく、 春山行夫氏の「満洲風物誌」を少し読んだだけで、自由ヶ丘に本屋あさりに出かけ る。偶然、八木隆一郎君に逢ひ、コーヒーを飲みながら語る。

昼食に魺の新しいのが手に入ったので、ぬたにし、少しばかり酒を飲んで寝 る。

“ナポレオン”十部(偕成社)送り来る。

午睡後、洗足駅近くまで散歩し、小包紙やインクを買って帰る。

夜、自分も手つだっでナポレオン”を小包にする。

(吉田、百田、篠原、内山、西村、少女俱楽部、少年俱楽部、山本克実、上 泉、岸田の十氏）

西田君に礼状を出す。

日本演劇協会よりバッヂ送り来る。

10月16日 (木) 晴

満洲紀行(仮題)第四日。

やはりペンが下せない。いつものやうに重ッ苦しい気持ではなく、むしろ胸 がをどるやうな気持で、なかなかペンが下せない。 
材料整理一観光東亜の索引などこさへて今日の仕事を終る。

山梨日々の座談会の件につき阿部欽一君より手紙。一一ずに近藤春雄君に同 封して手紙を出す。

大阪放送局より原稿受領、並に原作の返却を乞ふ旨の電報。さっそく速達で送 る。西村俊成氏 (幼年クラブ) より明日午後三時訪䄈る旨の電報。

宮下氏来訪。

第四次近衛内閣総辞職。

10月17日 (金) 晴

満洲紀行(仮題)第五日。一今日は休養。文献の整理。

…始の予定を変へて悠々と書く決心をして、今日は書くことを止めた。

朝、焚火一湯をわかしては消炭をこさへる。その湯でみんなは髪を洗ふ。

宮下君来訪。洋子京子をつれて五反田に映画を見に出かける。

西村氏(幼年俱楽部)来訪。

夜、安藤君来訪。

大命、東條陸相に降る。

10月18日 (土) 雨

満洲紀行 (仮題)第六日。一今日も休養。洋子京子に作らせておいた満洲に関 する文献のカードにより目録を作る。

登美子と新宿に出かけ、武蔵野館でスミス都へ行く”を見る。ジーン・アー サー、ゼームス・スチュアートの主演。なかなか面白い。中村屋でコーヒーを 飲み、シューマイを買って帰る。

東條内閣成立。…組閣拝命より二十時間にして成る。

鑓田研一氏より返事(黄風脚色の件)。

百田宗治氏より葉書(ナポレオン受取)

○10月19日(日) 晴

満洲紀行(仮題)七日目。一今日も○休養。殊に今日は完全な休養だ。

八幡宮参拝、郵便局一本局(童話春秋社長に速達その他)へ散歩を兼ねて京子と ともに出かける。

昼食後、あまりに天気がよいので京子をお供に再び散歩に出、兄の家に行 
く。兄、五反田まで送って来、白木屋でお茶を飲む。

夜、安藤君来る。同君に頭髪を刈ってもらひ、お湯に行き、二人で一杯や る。

入浴ヒゲそり中、少し寒かったが少し風邪をひいたやうだ。

受信一西田利明君その他。

発信一篠崎仙司、北尾虎男、園池、阿部欽一の諸氏。

10月20日（月）晴

満洲紀行 (仮題)一時中止。

北辺開拓の先駆者たちを書く。

準備としての読書。

昨夜、風邪をひいたのか少し頭痛がする。午睡、散歩、焚火。 夕食に一杯やり、催眠剂を服用して早目に休む。

夜、篠崎仙司(童話春秋社)

10月21日（火）快晴

昨夜は風邪薬の外に催眠剂を二服も服用して寝て、よく眠れたが、その代り 薬効がまだ頭に残ってるるせるか、まるで頭がもうらうとしてるる。

手紙を書いたり、焚火をしたりして午前中を過してしまふ。

嫂が来る。昼食後、少時ウトウトとし、散歩して来たら幾らか頭がはっきり して来たので、明日甲府で話す話をまとめておからと思ひ、演劇に関する本な ど読むが、余り頭に入らない。

夜、登美子に明日(旅行)の用意をさせる。

発信一西田、今村(偕成社)、鑓田、三上、その他往復葉書の回答。

受診一三上、芦谷、戸村、金谷完治の会その他。

10月22日 (水) 快晴、※欄外に「甲府」と書き込みあり。

六時起床。八時新宿発甲府行の汽車に乗る。同行の筈であった阿部欽一君(満 洲移住協会) は打合せの都合で昨日先行したさうで、芝田君が同行。小林宗君や独 立舞台の人々も一緒。

十一時甲府着。山梨日々の佐藤君や山梨文化協会の石原文雄君等の迎へを受け 駅前の東柳屋に一休みして、開拓展覧会を柕き、山梨日久新聞主催の開拓文学座 談会に出席。‥私を中心にしての集り。

田郷、阿部、小林、石原その他二十人ばかり。

散会後、佐藤君石原君の案内で竹屋旅館に投宿。 
三人で一本づつつけさせて夕食。食後県会議事堂に行き、“独立舞台”の舞台稽 古を覗く、

十時、宿に帰る。阿部君や芝田君と枕を並べて寝る。

○10月23日 (木) 快晴、※欄外に「甲府」と書き入れあり。

八時起床。阿部、芝田両君は朝から宿の温泉に入る。私は風邪を恐れて入ら ず、ヒゲを剃る。

ゆっくり朝食をすまして、宿を引上げ、梅月堂でコーヒーを飲む。

佐藤君(山梨日々)の案内で、サド屋を訪問。そこの主人から色々ブドウ酒の 話を聞き、醸造場を見学。

独立舞台の公演一「爾榮村建設」と「転業する家族」を見る。

サド屋のブドウ酒三本 (一本二円五拾銭)を買ひ、阿部君と二人で帰りの汽車に 乗る。芝田君と佐分利君(拓務省)が送ってくれる。

九時新宿着、防空演習中で薄暗い東京に帰る。

留守中に来たたくさんの手紙を読み、ブドウ酒を飲んで眠る。

○10月24日(金) 快晴

甲府で世話になった人久に葉書で礼状を書く。阿部欽一君にも手紙を出す。

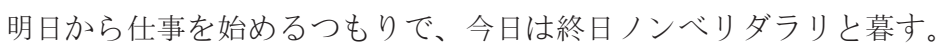

本格的防空演習の第二日目。

夜、鑓田研一原作、田郷虎雄脚色のラヂオ小説「黄風」大阪より放送一八時から の都市放送。五○分。ちやうど空襲警報の最中だったが、一家で聞く。割に面白 い。

※欄外に「ラヂオ小説「黄風」放送の日」との書き入れあり。

○10月25日（土）快晴

今日から仕事にか〉るつもりだったが、何となくクウクウバクバクたる気持 で終日今日も漫然と暮す。

正に小春日和で日中は、むしろ暑い位だ。加藤武雄氏以下数人の人々に“ナポ レオン”を送る。

防空演習正午までで終了。

午睡、散歩、焚火…焚火は、つひに私の趣味だといふことになり、その材料 を登美子、笠原さんのところからもらって来る。

(※以後の同日空欄部分に、同年10月26日の「補遺」が書かれている)

10月26日（日）晴

洋子、京子の運動会。…洋子が就学してから十一年、京子が七年、その間、 
両親そろって運動会を見てやったことが一度もないといふので今日は登美子と ともに府立第八に出かけることにする。

出がけには雨が降って気を揉んだが、学校に着く頃には晴れる。香世子ちゃ んを連れて来てるる嫂とも一緒になり、のんびりと運動会見物。……全く、か うした気持に浸ることは絶えてなかったことだ。

運動会のベンチで弁当を食べる。

三上文子嬢に、その師の大柴円○女史の絵の展覧会を見にゆく約束をしてみ たので、登美子とともに新橋駅に出かける。約束の一時に丁度半時間遅刻。三上 君とその友人の手塚さんといふのと四人、上野の松坂屋に行く。絵を見、大柴女 史に挨拶し銀座に出、お茶を飲んで別れる。

五時から本郷湯島天神三楽荘における金谷完治君の送別会に出席

※欄外に「十月二十五日欄につぶく」と書き込みあり。

$(※ 10$ 月25日欄の空白部分。 $)$

十月二十六日の補遺…

金谷完治君…名古屋放送局業務課長に栄転。

サトー・ハチロー氏と隣同壳となり大いに語る。

西沢、永井の両君と上のでお茶を飲んで別れる。

10月27日(月) 晴

久しぶりに朝寝。…早起きのくせがつき、午前中に仕事をするくせがついて し○まってみるので、朝寝すると仕事の調子がつかない。焚火をし、鼠を火 葬する。思ひきりもう一日急けて、思ひきりよく明日から仕事にか〉らうと思 ひ、登美子をつれて日本劇場に出かける。いつも招待券を無駄にするので今度こ そ使はうといふわけだ。運動会の翌日の休みで、洋子京子が留守番。文化映画 「土に生きる」は大変よい。レヴュー「志願兵」の作者島公綪君に逢ふ。

銀座を回って帰る。

夜、宮下君遊びに来る。甲府みやげのブド一酒を飲む。

二十七日夜もしくは二十八日夜に来ると言ってるた篠崎氏今日はつひに来な かった。

10月28日 (火) 晴

今日から仕事をする気になり、朝食後直ちに八幡さまに詣る。

ストリーを考へるために新聞の整理をする。正午までか〉ってもまだすまな い。午後の散歩に「ナポレオン」十一部、自分で送りに行く。それから帰ってま た新聞の整理にか〉ってるると、篠原君(誠文堂)より電話してくれとの電報。「亜 細亜の柱」出版に関する打合せのために逢ひたいとのこと。こちらから出かけて 
行き、今年一ぱいに出す約束をする。…手を入れるために切抜をもらって帰 る。‥吉田松陰の母を買って帰る。

10月29日 (水) 晴

「亜細亜の柱」改定第一日。

終日右の仕事をやる。

改定の必要なき部分は切抜をそのま>使子が、それにはどうしても二部づつ ある方がよいので、自由ヶ丘、大岡山、並びに付近の古本屋より買集めて全部 (子供の科学)手に入る。

父より直之君の嫁さんがきまった旨の手紙。

10月30日（木）晴

「亜細亜の柱」改訂第二日。

前編(第一章より第八章まで)完了。

秋永芳郎君より速達。一友人河内仙介君が顧問をしてるる泰光堂より新冒険少 年小説を出版するにつき一冊引き受けてくれないかと、その条件を述べて 依頼己来る。

メ切を二月十五日までにしてもらへるならばとの条件づきにて承諾の回答を 出す。(速達)

仙台放送局より「愛国回覧板」放送使用料十円送り来る。

冨美枝より小包(干鮙、するめ等)。

10月31日 (金) 晴

「亜細亜の柱」改訂第三日。

完成した前編く八章分〉を篠原君(誠文堂)宛速達書留にて送り、十一月号の「子 供の科学」並びに十二月号文の校正を送ってくれるやう速達を出す。

11月諸事要録

執筆

小説「亜細亜の柱」改訂(出版のため)

130枚

劇「新穀感謝祭の宣誓劇」

5枚

伝記「北方開拓の人久」

30枚

序文「亜細鱼の柱」あとがき

5枚

計

170枚

収入

「厚生列車」『日本の風俗』

26円 
『ナポレオン』(偕成社)印税

1176.4円

「亜細亜の柱」『子供の科学』11月号

新冒険少年小説(泰光堂)

200円

ラヂオ小説「黄風」(JOBK)

100 円

計

1565.4円

11月1日（土）晴

「亜細亜の柱」改訂第四日。

阿部欽一君に「ナポレオン」を送る。

園池氏より手紙。アサノ児童劇学校の招待券を入れ、福岡信夫君の作を見てほ しいとの依頼。

11月2日(日) 晴

「亜細鱼の柱」改訂第五日。

疲労のため成績不良。京子を連れて芝の青年会館にアサノ児童劇学校に児童劇 祭を見に行き、福岡信夫君に挨拶し、同君の「アサヒコのユメ」だけを見て帰る。

夕、兄一家、美枝夫人母子、宮下、安藤の諸氏来遊。夕食を共にする。

11月3日（月）晴

「亜細亜の柱」改訂第六日。

(※以下、㧺そらく翌日11月4日の内容と思われる文章が八行書かれている が、塗りつぶされている。)

第九章より第十二章まで完成。速達書留にて送る。

安藤、宮下両氏来訪。長い間の懸案であった棚を作ってくれる。夕食に一杯 やる。

11月4日 (火) 晴

「亜細亜の柱」第六苩目。

嫂来訪。

午後三時頃、日本文化中央連盟の池谷氏より「オネガヒシタキコトアリ、オデ ンワオネガヒマウス」旨の電報。電話すると、是非至急にお願ひしたいことがあ るので、お逢ひしたしとのことなので、大阪ビルに訪ふ。新嘗祭の前日に行ふ 「新穀に感謝を捧げる会」に於て行ふシュプレヒコールやうのものを創作してく れとの依頼である。今月は特に忙しいので当惑するが、催しの性質から考へて 無下にことはるわけにも行かないので、仕方なくひきうけて帰る。

○11月5日(水) 晴

「亜細亜の柱」第七日目。

新しく書加へる少年工の生活につき調べたきことあり。都合よく樋口忠雄氏 
が——妻子を郷里に迎へに行って数日不在だったのが、帰京してるるので、一時 間ばかり来てもらって、色々と話を聞く。大いに役に立つ。

が、気持としては創作的にまとまらないので、一日休養するつもりで、登美 子をつれて銀座映画劇場に大船の「桜の国」を見にゆく。脚本には大いに不満があ るが、演技その他は中々面白い。二度くりかへして見てもよい位であったが、 子供たちが待ってるるだらうと思ひ、ひとしきり見るや直ちに銀座の美松で コーヒーだけ飲んで帰る。

秋永君と泰光堂より明六日夕食を共にしながら、新冒険少年小説出版に関する お打合せ約し度き旨の手紙あり。

\section{1月6日 (木) 晴}

「亜細亜の柱」改訂第八日目。

正午まで全部完成。枚数は二百七十枚ばかりだが、その間には多数の切抜が あり、それは一段分で原稿紙二枚位に当るので正確な数は分らぬ。

が、とにかく順調にこ〉に改訂を終る。八日間を要したわけだ。予定よりは 二日ばかり遅れたが、その位は仕方あるまい。この八日間、毎晚酒によって眠 り毎朝早く起きて、主力を殆ど午前中に注いだ。

午後一時、家を出、誠文堂に篠原君を訪ひ、原稿を渡し、打合せをする。

田村君より「亜細亜の柱」の校正一台分を受取り、「吉田松陰の最後」を買って銀 座に出る。

(※ここに、日記帳上段、1940(昭和15)年11月6日の空欄に書かれた挿入部分 を入れるよう指示がある。以下、挿入分。)

日比谷書房にて「明治維新水戸風雲録」(九円)を買ふ。ブラジル、千㱜屋、更 科等で時間をつぶし、○神田に行く。まだ時間があるので、明治製菓でコー ヒーを飲み、夕刊を読んでから、今夜の会場である濤龍(博品館の裏)に行く。

(※以上、挿入部分終わり。1941年11月6日の欄に続きが書かれている。)

新冒険少年小説出版に関する打合せ会。

主宰者側 $\cdots$ 泰光堂社長・鈴木吉平氏、河内仙介氏、秋永芳郎氏。

執筆者側‥田郷、梶野千万騎、泉本三樹、大庭鉄太郎の諸氏。

印税の内金二百円を受取る。

八時半散会。

秋永君今夜九州に向ふ。

○11月7日 (金) 晴

杉久君(令女界) より読者文芸欄の散文を昭和十七年一ヶ年引受けてくれぬかと の速達。承諾の返事一速達。 
泰光堂より契約書送り来る。秋永君より提示ありたる書下し料のこと文面に なき故それを加へてもらひたき旨を申送って、契約書を返す一速達。

篠原君に「亜細亜の柱」の校正一速達。

今日は文化連盟の依頼による「新穀に感謝を捧げる会」のシュプレヒコールを 書くつもりだったが、「亜細亜の柱」の疲れを休めるため、午前中は和田政雄の「 間宮林蔵」を読んだだけで過す。午後は平塚に古本屋を司見きに行き、叢文堂で黒 龍会編「西南記伝」六冊 (八円)、朱印船貿易史 (四円五○銭)、明治維新運動人物考 (二円一○銭)を買ひ、届けてもらふことにする。

タ方は久しぶりで焚火などして過す。

11月8日（土）晴

日本文化中央連盟の委嘱によるシュプレヒコール「新穀感謝祭」一実に迷惑な 仕事といはねばならぬ。今日も感興わかず、終日無厚にして過す。

夜は男の隣組常会で、酒井氏宅に集まる。和田、笠原、田郷、田中、酒井の五 人。十時まで雑談して散会。

安藤、宮下両氏来る。本棚をつくるためで、安藤君は泊ってゆく。

「带細带の柱」校正一台分(第四章)速達にて送り来る。

泰光堂より、こちらの要求どほりの条件記入して契約書送り来る。

直ちに、速達にて調印送付。

11月9日(日) 晴

「亜細亜の柱」(第四章)の校正を自分で速達に行く。

宮下君も早くからやって来て、誓君と二人で、縁に大きな書類整理棚をつく

る。○手つだひはしなかったが、私もつひに仕事は手につかず終日ぶらぶら

して過す。

三時頃に大きな書棚完成。それより台所の棚、流し場の棚にか>り、六時頃 終了。三人でお湯に行き、夕食に一杯やる。

「亜細亜の柱」十一月号分の稿料やっと本日とぶく。

・11月10日(月) 量、※「・について欄外に「昼」と書き入れがある。

今日こそ「新穀に感謝を捧げる会」のシュプレヒコールに着手のつもりで、 朝、八幡さまに詣で机につく。が、つひに今日も中止して、「北進日本の先駆者 たち」を読む。

日本文化中央連盟より進行状態を問ひ合せる電報来る。散歩がてら自分で「明 日送る」旨返電を打ちに行く。帰りに○○古本屋をのぞき、藤川三溪の伝記を 買って帰る。 
朝、秩父四郎君(ハルピン)より手紙。

登美子に誠文堂より送って来た六十三円を受取りに行かせる。

11月11日(火) 量、午後は幾分よくなる。

新穀感謝祭の開幕劇(シュプレヒコール)今日中にも送る旨の返電をしてるる ので何とかしなければならないと思って焦るが、どうにもうまく行かぬ。悩ん でるるとさらに思ひがけなくも天津の山口清君夫妻来訪。…近く一度上京すると は言って来てるたが、その前に予告があると思ってみたので、不意打であっ た。

家で昼食を共にし、新婚を祝ふつもりで一本つける。同君等辞去の後、午 睡。

夜、全くうつつともなき心で新聞など読んで時間をつぶす。 辛い。辛い。書けないことは苦しい。

ほとんど暮れ方近くになって来た郵便二種一雑誌「機械化」と「日本学芸新聞」の うち、後者に本年度の日本農民文学賞の八つの授賞候補作の中に私の“螟蛤子”が挙 げられてるるのを見て意外に思ふ。

11月12日(水) 晴

苦しみぬいた六日間——っと「新穀感謝祭宣誓劇」五枚脱稿。直ちに日本文化 中央連盟に持参。池谷君に手交。一一行き違ひに(留守中に)池谷君より原稿いた だきに上る旨の電報あり。

運動のつもりで銀ブラ。三昧堂、紀伊國屋、近藤書店、伊東屋。一伊東屋で紙 はさみ、紙類。近藤書店で田中惣五郎の「維新読本」を買って帰る。

家に帰ると、平戸の姉さんから一一冨美枝に頼んでるた「するめ」と魺の錐詰 が来てみたので、それで昼食。

食後、疲労を感じ、机のまはりの整理などをして時間をつぶす。

山口清より神田に宿を変へたる旨の速達。

夜に入って「亜細亜の柱」の校正したるか送り来る。

今日も酒で眠る。

11月13日 (木) 量、夕方より雨

久しぶりに七時のラヂオ体操をやって、直ちに「亜細亜の柱」の校正にか > る。分量が多くて疲れもしたし、これから速達したのでは遅くなると思ふし、 それに山口(清)にも一寸ぐらあ顔を出さないといけないと思ふので、誠文堂に持 参することにする。

幸ひ、篠原君がるたので、コーヒ一を飲みに行き、旅行のことなど打合せす 
る。

鎌倉館本館に山口君を訪ふ。不在。名刺の裏に訪ねて来た旨を記して番頭に預 け、古本屋めぐりを思ひ立つ。久坂玄瑞を探すため。軒並に歩いたがどうして も見つからない。「吉田松陰の殉教教育」と徳富蘇峰の「吉田松陰」(共に新本)を買 ひ、丸善で紙はさみなど買って新宿に回る。チヤンポン屋で洋粉なるものを食 べて帰る。篠原君より受取って来た校正二台分を速達しに自分で出かける。

山口君、明日帰るとて、挨拶に来る。

11月14日 (金) 晴

夜中三時に目がさめ、そのま>床の中で「北進日本の先駆者たち」中の松浦武 四郎を読む。非常に面白い。この男が平戸と関係があるとは知らなかった。そ のうち、もっと調べてみようと思ふ。

今日は「北方開拓の人久」にか>る予定だったが、止して終日読の書。

太平堂に取次を頼んでるた維新史三巻がとぶく。一冊四円八十銭づつ。案外安 い。

登美子、昨夜より気分が悪いと言って、終日寝てるる。

午睡。入浴。レインボーグリルの上澤謙二氏の文筆生活二十五周年慶祝会に出 席。篠崎仙司、野口青村、黒崎義介、丸尾文六の諸氏と語る。

テーブルスピーチは安部季雄、久留島武彦、沖野岩三郎、岸部福雄、横山美知 子の諸氏。

散会後、黒崎氏と新橋駅付近のおきな屋(?)といふおでん屋に寄り、一ぱいや りながら語る。

前記の会で久しぶりに内山憲堂君と逢ふ。

11月15日（土）晴

今日も亦、夜中の三時に目がさめて閉口する。そのま〉起きて「○○北進日 本の先駆者たち」を読む。

野口青村君に古橋中佐に贈る「ナポレオン」を送るべく小包をする。つひでに 穂積と相浦の叔父さんにも送ることにする。

今日も「北方開拓の人久」を止して終日前記の読書。国田兵右衛門、光太夫、小 栗重吉、郡司成忠、福島安正、全部読了。どれも面白いが、殊に光太夫と小栗重 吉は頗る面白い。前者は青少年の読物に、後者は純文学作品に恰好だ。

野口青村君より「樺太探検の人々」送り来る。

園池、大島両氏より返事。日本文化中央連盟より二十二日の催の招待来る。

登美子、山田病院に行き、太田君よりもらひたる薬を注射してもらふ。 
美枝夫人母子来訪。七五三のお祝ひである。

○11月16日(日) 晴

久しぶりに少しく朝寝。昨日や一昨日の寒さにひきかへ、すばらしいお天気 だ。

「亜細亜の柱」の校正をし、自分で速達しに行く。帰ると、もうお昼だ。パン で昼食。食後午睡。洗足駅付近まで散歩。そこの本屋に、伊藤整君の「満洲の朝」 が出てるる。見ると、一昨年の旅行記なので買って来る。

帰ってみると、偕成社より印税が来てるる。

宮下君来て、畠の手入れをする。

夕食に一ぱいやる。それが終ったころに安藤君も来る。

登美子、今日も山田さんに注射に行く。

11月17日(月) 晴

珍しく九時まで誛込んでしまった。全く近年珍しいことである。

やっと「北方開拓の人久」の執筆にか〉る。

登美子、今日も山田さんに注射に行く。帰ってから、尅服橋の安田に小切手 を落しに行く。ところが、横線小切手だったので、今村氏の記名择印が必要だと いって帰って来た。それで自分で出かけることにし、偕成社に今村社長を訪 ひ、社員に現金に替へに行ってもらふ。

五反田に回り、安田銀行支店に、七百五十円だけ、特別当座にする。

夕方「亜細亜の柱」の校正送り来る。初校はこれでおしまひである。さっそく 校正を○して自分で速達しに行く。帰りに太平堂により、便箋紙と山田健二氏の 「国境のお友達」を求めて帰る。

「亜細带の柱」序文も今日のうちに書くつもりであったが、さうは行かなかっ た。

お酒を飲んで眠る。

11月18日(火) 晴

六時前に起きる。庭をふらつく程度の運動で、さっそく「北方開拓の人久」に か>る。正午までで切上げる。

昼食後、古本屋を一軒々々のぞきながら大井町まで歩く。久坂玄瑞を探すた めである。つひに見つからず、中里介山の「吉田松陰」を買って帰る。

平戸の姉に手紙を書き、金二十円送る。今まで送ってもらったスルメの代と 今村氏に贈ってもらふつもりのスルメ代。自分で書留郵便に出しにゆく。

宮下君来る。夕食を共にし、入浴に行く。池田弁護士を訪机るために、七時 前に帰る。 
満日出版部に出版交渉の手紙を速達で出す。

11月19日 (水) 是、後雨

宮下氏の裁判…本人調べといふので同道することにする。まづ池田弁護士宅 により三人同道で横浜に向ふ。

裁判は十時に始まる。傍聴者は私一人。一時間ばかりですむ。三人で不二家 で昼食。雨の中を、桜木町駅に行き、熱海に行くといふ池田氏とヨコハマ駅で別 れ、二人で銀座に出る。西田君に贈る商品券を買ひ、新橋ですしを食べて帰る。

朝、風邪気味だったが、大したこともなささう。宮下君と○一ぱいやりなが ら夕食。

疲れてるるとて宮下君も早目に帰ったので、早く床に入ってるると安藤君来 訪。予て頼んでるた織物が出来て来たのである。又、二人で飲む。

西田君に小包と手紙を出す。

11月20日 (木) 晴

「北方開拓の先駆者たち」をつぶける。

午後一時から、農村共同建設連盟の招聘による同連盟と農懇演劇部員との懇談 会に出席。

出席者…藤森成吉、中村星湖、下村千秋、園池公功、大島万世、伊藤貞助、古 川良範、田鄉虎雄、森重書記長 (以上農懇側) 上泉秀信 (翼賛会) 外に連盟側数人と阿 部正雄氏。藤森氏、中村氏等の大先輩と私の意見は、かなりの隔りがあり、相当 激論する。

散会後、大島氏と二人で、園池氏を晚餐に招待する。良い場所がなく咫服橋の 「末広」で定食に日本酒で大いに談ず。園池氏には「満洲国」上演の後に夕飯なり招 待するつもりでるて、今日まで丁度十年のびのびになってみたわけだが、その ことを話して笑ふ。

嫂が大阪に行ってるるさうで、京子美知子のところに泊りに行く。

11月21日 (金) 雨

「北方開拓の先駆者たち」三○枚やっと完成。意外に日数を要した。

午後、疲れ甚だしく午睡する。目ざめたところに、「少国民日本」の編集者赤 松俊衞氏来訪。同誌二月号に児童劇を書いてくれとの依頼。忙しいのでの即答せ ず。数日後諾否を返答する旨を答へる。

夕食の代りに、ソロンタンを食べて、水道橋の宝生会能楽堂に出かける。日 本文化中央連盟主催の新穀感謝祭の芸能奉献としての第一日。今日は能の会。 
久しぶりに見る能なので面白く、おしまひまで見る。

寒気甚だし。今日はじめて冬外套を着て出たのだが、それでも寒い位であ る。

京子、今日も美知子のところに泊りに行く。

○11月22日(土) 雨

「北方開拓の先駆者達」の原稿を上沢氏に届けに行き、「亜細亜の柱」の序文を考 へる。うまく行かないので、少し早めに家を出る。軍人会館における新穀感謝祭 奉献芸能の買い(第二日)に出席のため。小用を催して来たので新橋駅に下りる と、偶然、安藤君に逢ふ。今晚、先日頼んだ電球を持参するといふので九時以後 に来るやう話す。

神田で古本屋を二三軒のぞいて、直ちに軍人会館に出かける。全然期待して みなかった私の作、宣誓劇新穀感謝が案外よかったので、うれしくなる。

古本数冊(長崎に関するもの)を求めて帰る。

安藤君、九時頃お酒持参で来り。二人で飲んで眠る。

今日は洋子も京子も美知子のところに泊りに出かける。

11月23日(日) 晴、夕より雨

「亜細亜の柱」の序文を書きにか〉るが、どうしてもうまく行かず、つひに投 出してしまふ。

登美子が酒井さんのところからもらって来た古木で焚火などして時間をつぶ す。

今日より魚類登録制になる。

登美子と阿部氏宅を訪ふべく家を出る。同君三人の亡児のため法要を営むと て予て招待されてるたのである。五反田、白木屋に寄って、冨美枝への帯、正子 和子へのハンカチ、阿部君のところへの手みやげなど買ふ。

阿部氏のところには、私一家の外に兄、美知子、宮下君、安藤君等集まる。 私は例のとほり寄って眠る。目がさめてみると徳田君が来てるる。

九時頃、帰る。京子だけは今日も美知子のところに出かける。

11月24日(月) 雨

「亜細亜の柱」の序文でどうしてもうまく行かないので、枚数を長くして「あ とがき」とし、五枚半書き、自分で誠文堂に持参する。幸ひ、篠原君がるたの で、同君にわたし、色々打合せをして「久坂玄瑞」を借りて帰る。

古本屋を二三軒まはり、「南進日本の先駆者たち」を求めて新宿にまはる。 チャンポンを食べ、エルテルでコーヒーを飲んで帰る。

菅沼貞風史の「日本商業史」の序文や跋を読み、この本を書いた貞風の偉さは 
勿論だが、この本の再刊を敢てした岩波書店の功を多としたいと思ふ。 たまってるる返事二三を書く。

11月25日 (火) 雨

山田健二の「国境のお友達」などを読みながら、児童劇の構想を考へる。 赤松俊衞氏 (少国民日本)に児童劇を引受ける旨を答へ、同時に稿料の額を一枚 三円以上と要求する。一速達で出す。平戸の塙董蔵氏に今まで滞らしてるた「平 戸之光」の誌代として金十五円を送り、その後の分の送付方を依頼する手紙を出 す。

この頃ずっと午後になると疲れる。午睡する。

夕方赤松君(少国民日本)より速達で返事。こちらの要求をよく理解した極めて 気持のよい手紙。

この頃ずっとさうだが、酒で眠る。

○11月26日 (水) 晴

今日は児童劇の構想を中止して、令女界の散文の選考をする。百篇からの原 稿を読むにはどうしても一日はか>る。が、大体目量もつき特選、入選を決定す る。

今日は結婚十九周年の記念日だ。

午睡。夕食、入浴の後、少し遅くなったけれど、東日児童文化劇場の試写会 に出かける。移動映画の「るもんぶくろ」は非常によい。ドイツの「体育の凱歌」 もよい文化映画。この映画を見てもドイツは相当すぐれた民族であることがわ かる。

映画がすむと、すぐ帰って、一ぱい飲んで眠る。

寝酒の癖が、すっかり病前の状態に還ってしまった。追々改めなければいけ ないと思ひながら、つい、不眠の苦しさから飲んでしまふ。

午睡中に北村六郎君来る。

11月27日 (木) 晴

令女界の選を決定し、選評を書き、小包にして速達する。散歩を兼礼て自分 で出しにゆく。

感激美談集など、ひっくりかへしてストリーを考へる。

穂積から「探検全集」日本編が送って来る。松浦武四郎のことや、幸太夫のこ とが詳しく書いてあるので、すっかり嬉しくなる。

昼食に一本つけさせて午睡。

夕食前、酒井さんからもらひうけた古竹や古材木で焚火をする。薪をもらひ 集めてまでの焚火の趣味は、われながら苦笑の外はない。 
山嵪醇之輔氏来訪。吉本で「お祖母さんと分数」(講談俱楽部所載) を上演させて くれとの相談。上演料が百円では安いと思ったが、素人劇普及の意味で、快諾す る。

夕食後日記の整理。

\section{1月28日 (金) - 暴風雨}

ひどい雨風。雨戸も開けられず○仕事をするのにも電灯をつける始末。

明方に目がさめて、それなり眠れなかったために、頭がもうらうとしてみ る。朝食後つひに酒を一杯ひっかけて眠る。一時間余り眠って起きる。が、仕事 出来ず。なんといふことなしに時間をつぶす。

頭髮が伸びて余計にうったうしいので勇を鼓して旗ヶ岡に散髪にゆく。

ずいぶん久しぶりだ。散髪にゆくのが年々おっくうになり、最近は家でばか

り刈らしてるたのである。

夕方どうやら天気もよくなったので焚火を少しやり、京子とお湯にゆく。

夕食の時にまた酒を飲む。眠る。八時頃さめて、いつかの残りの催眠剤を服 用して眠る。

“川中島合戦”(東宝映画)の試写案内状が速達で来る。

\section{1月29日 (土) 曇}

寝がてに酒を飲まなかったせるか、夜中に起きることもなく、それに催眠剤 を服用したわりには頭の調子もよいので喜んで、焚火をして、すぐに机につ く。児童劇を書くつもり。‥が、つひに出来なかった。終日焚火をして暮す。 夜、気持甚だよろしからず。仕事が出来なかったせるである。

東宝の試写には登美子をやる。登美子の退職金支払通知が、やっと来たの で、試写の帰りにとりに行くと言って出て行ったが、土曜日でもう間に合はな かったと言って帰る。

先日病死とニュースに出てるた関屋敏子(音楽家)は、芸術上の苦悶による自殺 なる由、夕刊に出てるる。

“樺太探検の人々”発行所より送り来る。

夜おそくなってから誓さん来る。

11月30日(日) 晴、寒い。

二、三週間前からの懸案だった「わが家の農園」の撮影にか〉る。撮影技師は 
誓さん。

どんなに焦り悩んでみても児童劇は出来さうにないので、サツペル女史の「 ペフリング一家」(愛の学校)を読む魂が清めらるるやうな書物。こんなものを私 も是非そのうち書きたいと思ふ。

宮下氏来る。木炭を持って来るとて一旦帰る。

美枝さん来る。

新宿の陶楽に行く。長崎文化協会の集会である。福田、本山、松本寅一、藤 浦、荒木十歩 (※荒木十䇉か) その他三十数氏。中々盛会で愉快なる会だった。自 分は満洲旅行のため、とうとう書けなかったが長崎文化物語も大変よく出来てる た。本山氏の指名により私も一席しやべる。帰りは藤浦洸君母と一緒。

\section{2月諸事要録}

執筆

児童劇「子どもと、ぶたいちやう」幼年俱楽部』』15枚

児童劇「長春健児団」『少国民日本』15枚

小説「黒竜江で」『令女界』18枚

感想 $「 大$ 国民の道」『読売新聞』2枚

計

50 枚

外に「日本の娘」の書直し50枚ばかり。

収入

「村に来た部隊長」『幼年俱楽部』』46.50円

「北方開拓の先駆者たち」 58.34円

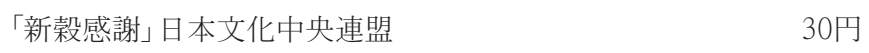

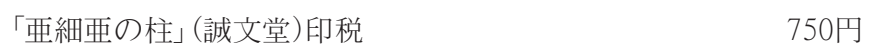

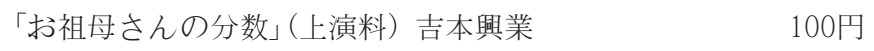

旅費(満鉄) 280円

「亜細亜の柱」『子供の科学』７5円

計—1339.84円

12月1日（月）晴

夜中に目がさめ、何とも胸が息苦しく閉口した。明けてから一睡して、久し ぶりに一人で朝食。

掃除がすむと登美子は市金庫へ退職金を受取にゆく。

つひに十二月となったが今日も仕事をせず、終日「続愛の一家」を読む。私も やがてはからいふものを書きたいと思ふが、もしもそれが理想的に出来た時 は、自分が死時ではないかと妙に静かな気持になって来る。終日涙ボロボロ こぼしながら読みつぶける。時々、宮下氏からもらった老眼鏡をかけたりしな 
がらい。

今井精 $\bigcirc$ 氏逝去の通知あり。

“平戸之光”送り来る。

\section{2月2日（火）晴}

わづか十枚余りの児童劇二篇のために、もう幾日無駄な日を過したことだら う。一体かうしてまで児童劇を書く必要が、どこにあるのだらう。古本屋に出 かけたり、人の作を読んだりして何とかストリーを考へ出さうとするが、頭は 硬直してしまって徒労にをはる。むしろ、やるせない気持になって午睡をす る。かなりぐっすりと眠り、後、付近を散歩する。

塙董藏氏に手紙を書く。

塙氏(平戸)より書面、小包(浦敬一)

昨夜は酒を止して、催眠剤で眠ったので、今日は少し酒でも飲んでと思った

が、どこの酒屋にも酒なく、いさ>か悄げ気味で寝につく。が、幸ひにして 安らかに眠れた。

12月3日 (水) 啨

出来た。とにかく、やっと児童劇「村に来た部隊長」(又の名、子どもと部隊) 十五枚は出来た! 枚数は約束より四、五枚超過してるるが、遅い目の昼食をすま して、自分で速達を出しに行く。

ひどく疲れてるたので、午睡しようかと思ったが、もう遅いので我慢するこ とにし、焚火をする。それから、蒲生治郷氏、近藤春雄君に手紙を書く。夜は台 湾の陳秋玉君から催促が来たので、同君の脚本「白雀」を添削し、批評を書いて出 す。

一両日来右の下の奧の歯が少し痛むので、夏目さんに行からかと思ったが大 したこともなささうなので我慢する。

塙氏、蒲生氏に「長崎文化物語」を送る。

12月4日 (木) 晴

「少国民日本」の児童劇にか〉るつもりだったが、中止。検印を捺す手つだ ひをして昼食後、家を出る。誠文堂に篠原君を訪社「久坂玄瑞」を返し、検印五千 五十枚を渡す。付近の喫茶店でコーヒーを飲みながら、打合せをしたり新しい少 年文学について語ったりする。

満鉄、東京支社に行き、開拓展を見、第一弘報に粕谷氏を訪ふ。

それから日比谷に出て「満洲で働く日本人」と「ソ連極東国境線」の二冊を買 
ひ、木挽町の山田家に行く。翼賛出版協会の、ふぐ料理の招宴。

上泉秀信、牧賢一、福田清人、岩倉政治、田郷、西川貞一、油谷、織田氏等出 席。ふぐ料理もちりの方はもう数回食べるが、さしみの方は始予てだったが、 なかなかおいしかった。

散会後、福田君と二人、同君なじみのバアに行き、気绉を上げて別れる。

○12月5日 (金) 晴

ふぐ料理のき〉めであらうか、朝から妙に神経興奮気味で仕事も手につかな い。一眠りして、産業組合会館における農建同盟の人形芝居研究会に出席。今日 は二回目で、阿部正雄氏のひきるる苳蕫座員による研究試演会を催し、小寺融吉 氏の講評を聞く。

散会後、園池、大島の両氏と例のごとくお茶をのみ、紀伊國屋をのぞいてか ら、新橋の大三元(支那料理) に行く。平戸会である。メンバー六人みな揃ひ、な かなか気持のよい集りで、上気嫌に酔ひ、千北君と東洗足まで同道で帰ったが、 家に帰って、踊り出すぐらる愉快だった。

速達二本、「明朗大陸」と明石鉄也君から。明石君は少女小説を出版させてくれ との相談。

12月6日（土）晴

(※冒頭3行が書かれたあとに塗りつぶされている。内容的に同日の日記を書 き直した模様。)

五時に目がさめたので、そのま>起き、明石君の依頼による切抜の整理をす る。少女小説も純文芸物の長編も今のところ恰好のがないので「南方の詩」とその 他の短編を、理由を添へて送ることにし、自分で速達を出しに行く。

「少国民日本」に書く児童劇のテーマとストリーは、やっときまったが、まだ 書く気にならず。ボンヤリと時間を過す。

夕方、西村氏 (幼年俱楽部) 来訪。「村へ来た部隊長さん」について、訂正を求め て来たのである。珍らしく、ゆっくりと話しこんで州る。

安藤君、農園の写真を持って来、泊ってゆく。

速達日本、農山漁山文化協会と満鉄東京支社加ら。講演旅行の件、決定。

12月7日（日）快晴

いよいよ忙くなって来た。昨夜、仕上げた「村へ来た部隊長さん」を京子に速 達にやらせる。同時に、福田君と篠原君に、九州旅行に関して速達を出す。

「少国民日本」の依頼による児童劇を書く。「長春健児団」十五枚。午後一時ごろ 
出来あがる。なかなかよい出来である。洋子と京子に書留で出させる。

12月8日(月) 晴、※欄外に「今晚、九州に向って出発」と書き込みあり。

昨夜遅くしか眠れなかったので朝寝をしてしまふ。十一時には福田君と満鉄 東京支社に落合ふことになってみるので、用意をして出かける。新橋駅前で珍ら しく号外売が出てるるので、買ってみると、いよいよ対英米戦の記事だ。非常 なショックをうける。満鉄に行き、粕谷氏や近藤氏と打合せをしてるると、福 田君もやって来る。それと一緒に誓君もカバンを持って来てくれたが、これは すぐに帰り、○○福田君も加はって再び打合せをしてるると、十一時三十分から 対米英宣戦布告に関する臨時ニュースが放送されるから、屋上に集まるやうにと のぶれが回って来る。私たちもそれを聞くべく、社員とともに屋上へ出る。み んあが沸り立つ胸をおさへてニュースを聞く。その後で満鉄東京支社次長が壇上 に立って、一場の訓辞を述べる。

一以下補遺欄に $\cdots$

※欄外に「対米英戦線布告」との書き込みあり。

(※以下、巻末の1941年分の補遺欄)

○戦線の紹塖一十二月八日の記

「つひに時は来たのです。われらの大和魂はをどり立つのであります」

次長の声はふるへ、その㚘には涙が流れてるる。そこに集まった凡ての社員 が同じ思ひだ。

私と福田君は奇しくもこの歴史的重大な日に東京を発って九州に講演の旅に 赴かなければならなかった運命を、むしろ喜びながら胸をひきしめた。

近藤君の相伴で三人がアジヤ食堂で昼食をとらうしてみると、ラヂオが「君が 代」を放送し出した。と、食堂にるた悉くの人が、さッと起床君して頭を垂れ た。やがておごそかに宣戦の紹柺が復唱奉られ、つぶいて東條首相の「紹務を拝 し奉りて」なる放送が行はれた。われわれは緊張の余り食事の味もわからなかっ た。

やがて旅費二百八十円を受取り、福田君と今晚の打合せをして一旦別れるこ とにして街に出たが、地下鉄虎の門の入り口は○○新聞(この日は午前中にタ刊 が出た）を買ふ人がエンエン長蛇の列をしき、巷をゆく人々の顔は明るく張り きってふるのを、われわれははっきりと感じた。

一時に来ると言って来てるたのを、○三時に来てくれるやうにと電報してる た明石鉄也君は3時半頃やって来た。三㟝書房から出す「南方の詩」についての打 合せや契約のためである。契約をすまし、今夜の出発のことを語り、後日を約 して早々に帰ってもらふ。

入浴、神仏を拝して夕食の膳につき、登美子をはじめ洋子京子に、いよいよ 
対米英戦となったについての、特に留守中の注意などを言ひ聞かせる。時が時だ けに、みな緊張して聞く。

戸外は、既に警戒管制が発令されて暗くなってるる。隣組長としての和田さ んにだけ挨拶して早目に家を出る。

東京駅には、福田君はまだ来てるなかったが、満洲移住協会の芝田君が来て をり、同君と話してるるうちに、福田君も来り、三人で食堂に行き、ソーダ水 を飲んでいよいよ汽車に乗る。

十時十五分東京発の普通列車に乗り、い上い上宣戦布告の夜、東京を出発す る。昔と違って近頃は一体に二等車は混むやうであるが、今日は特に宣戦布告と ともに郷里へ帰らなけ机ばならない人々が乗込んでるるために、殆ど満員に近 く、なかなか誛苦しい。

12月9日 (火) 雨、寒し

退屈な車中の一日も、対米英宣○戦布告の緊張と興奮で何とか凌ぎ、夜、下 関から門司にわたる。どちらも徹底的な燈火管制で、登美子の注意で携へて来た 懐中電灯がさっそく役に立つ。冷たい雨の中に青木源之助氏 (満鉄、鮮満支案内所

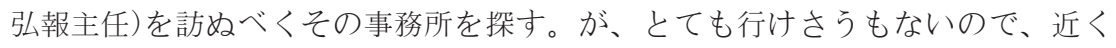
の喫茶店に入り、電話をかける。すると、青木氏も僕等を案内するため、明日長 崎へ出かける由なので、喫茶店でニュースなどを聞き、長崎行の汽車に乗る。幸 ひ、二等車はガラあきではあったが、スチームがこわれてるるとかで寒いこと 甚だしく殆ど眠れなかった。

12月10日 (水) 啨、※欄外に「長崎」と書き込みあり。

汽車は延着して、七時五十分頃、長崎に着く。駅には相川貞雄、松尾任等の級 友と長崎鮮満支案内所の下荒磯開吉等が迎へに来てるる。ほとんど二十年ぶりで 訪れる長崎だ。むろん、なつかしくないことはないが、それにも増して相川や また予期さへもしてるなかった松尾君等が迎へに来てるて、なにかと友情を見 せてくれたことが嬉しかった。福田君は一旦その地の親戚の家に行くことにな り、私は相川と下荒磯君に案内されて宿(諏訪荘)に行く。諏訪神社の下にある品 のい〉宿である。

そこに旅装を解き、前期の二人と話をしながら朝食をとる。

後で迎へに来てくれる約束で、下荒磯君まづ帰り、相川も後でゆっくり来る ことにして一旦帰る。

補遺欄につぶく

(※以下、巻末の1941年分の補遺欄) 
○長崎にて一十二月十日記

…茶代を奮発して、よい室にとりかへてもらふ。南向きの頗る気持のよい部 屋である。女中もみんな訓練されてみて感じがよい。

しばらく休まうと思ひ床をのべさせたが、○講演の腹案が出来てるないの で、少し調べものをする。さうしてみるらちに、すぐに正午になり、待望の チャンポンをとってもらふ。

が、材料がないためか、もう昔のチャンポンではない。午後も調べものをす る。やがて福田君が訪权て来る。図書館に立寄るといふ福田君にさきに出ても らって、調べものをしてるると今度は講演の始まる時間で、満鉄支所から下荒磯 君が迎へに来る。同道で図書館に寄り、増田館長その他に逢ひ、会場で或る長崎 高商に赴く。…最初の計画では大きな会場を使ひ県の後援を得て大講演会にする 手配になってるたのだそうだが、とつぜんの宣戦布告で、寄るの大きな集会は 不可能となり、高商の講堂で行ふことになる。高商の生徒や教授たちを中心に国 民学校の先生を加へた六十人内外の集り。伏見義夫教授の挨拶の後、まづ福田君 から始める。私はそれにつぶいて厚生船の見聞談を中心に満ソ北部国境の重要性 につき語る。割によい出来で、生徒も真面目に聞いてくれた。二人の講演後、座 談に移る。なかなか熱心な質問が出る。

…の会には相川君が出席してくれたばかりでなく、思ひがけなくも、わざ わざ土井良井君が来てくれたのは嬉しかった。

われわれと同行して万事の手配するために出て来られた門司鮮満支案内所の 弘報主任青木源之助の挨拶でこの会を終り、夜、満月で懇談会。これには県から 職業課長以下二三の人も列席した。また満鉄長崎支所の主任柳谷善吉君が穂積の 同空生であったことも奇縁である。

散会後、燈管下の長崎の街を電車で宿に帰り、相川君にも宿に泊ってもらっ て語る。

12月11日 (木) 晴、※欄外に「長崎一佐賀一武雄」と書き込みあり。 記載なし。

12月12日 (金) 晴、※㦨外に「武雄一熊本」と書き込みあり。 春慶屋(武雄)の一室で目が覚める。

ひどく寒いので、三人一緒にゆっくりと朝湯につかる。すばらしく御馳走の 朝飯をすまして宿を出る。今日は熊本で講演だ。正午頃、熊本駅につく。福田君 の友人で、○地○方文化のために働いてるる荒木精之君が迎へに来てくれてる る。同君とともに千徳デパート内にある旅行案内所に行き、今日の手配を青木さ んに委せる。二人は荒木君に案内されて松の井旅館に旅装を解く。青木氏の帰る のを待ちながら時間をつぶす。 
午後六時から、支那料理屋 (名前は忘れた) で九州新聞社の宮原虎孝氏その他数 人を迎へて座談。それがすむと、すぐ宿に帰り、風呂にも入らず寝てしまふ。

12月13日 (土) 雨、昙、※欄外に「熊本一大分一別府」と書き込みあり。 松の井旅館(熊本市)で目がさめる。

朝食をすますと、さっそく係の女中としちやんに傘を持って電車の停留所ま で送ってもらひ、熊本駅に行く。九時二十二分の汽車で大分に向ふ。豊肥線に乗 るのは始予てである。いはゆる九州横断線であるが、生憎の雨で、阿蘇の噴煙 を見ることが出来ないのは残念であった。が、二等車はわれわれ三人きりで、 至極のんびりとしてるる。午後二時三六分大分着。迎へに来てるてくれた大分新 聞の山本益樹に案内されて直ちに講演会場である大分文化協会の会館に行く。

集る人久は、大分新聞、豊洲新報の両編集局長、高工教授、師範学校長、国民 学校長教師その他の三十人ばかり。自分の話は可もなし不可もなしの中位の出 来。

以下七月二十九日の欄に

(※1941年7月29日の空白部分に、続きが書かれている)

十二月十三日の補遺…

二人の公演後、座談会。それがすんで主要人物数人○と、—料亭の名を忘れ たが、市のレストランで懇談晚餐会。その席上で今日の講演会に大分文化協会演 劇部の数人が、ちゃうど私の作 (桜咲く丘の上と、ある日の水戸黄門)を練習して るるといふので、特に私のその方面を聞きたがってるたといふことを大分新聞 の山本氏から聞き、こちらも残念に思ふ。

散会後、電車で別府に向ふ。途中で小用を催し私だけ降りる。が、やがて清 風荘に旅装を解く。

12月14日（日）晴、※欄外に「別府」と書き込みあり。

清風荘(別府)の一室で目がさめる。

ゆっくりと三人で朝湯につかる。久しぶりに、これもゆっくりと朝食をすま し、福田君と二人で宿を出る。…青木さんは半日のヒマを利用して、この地に病 臥中の令息を見舞ふとて居残る。

宿のすぐ近くから出る地獄めぐりのバスに乗る。血の池地獄、海地獄、かま ど地獄、坊主地獄、八幡地獄などと、東京を出て以来、はじめてのんびりと見て 回り、海地獄ではお上りさんよろしく福田君と二人カメラにおさまったりす る。きっかり二時間でバスはもとのところに帰る。東洋軒で昼食をとり、二人 でまたのんびり別府の市内を見物し、みやげものなど買求める。

宿に帰って、二人で葉書の寄せ書など○してるると、別府市観光課○主任 
の中島辰夫氏から電話がかかり、やがておみやげのパンフレットなど持って挨 拶に来られる。そのうち、青木さんも帰って来、夕食。女中のユリさんに寝酌 の用意など齐だって今夕の座談会場南風荘に出かける。

一以下七月二十八日の欄に

(1941年7月28日の空白部分に、続きが書かれている。)

十二月十四日の補遺…

参会者…別府市助役福田潤氏、大分高商講師都甲文雄氏、市会議員佐藤福治氏 その他市の有力者たち○三十人ばかり。今までの中では最も粒が揃ってるるの で、却って話がらくだ。

福田君の義勇隊を中心にした話のあとをうけて、約四十分ばかり厚生列車の 話を中心に、満ソ北部国境のことについて語る。調子なかなかよろし。長崎の場 合とともに自分としてはよい出来だったやうに思ふ。とにかく、これで今季の 旅行の任務は終了した。小雨の中を三人 (福田、田郷、青木) 宿に帰り、一風呂浴 びて寝酷三本を飲んで眠る。明日は帰途につく。さう思ふと嬉しい。

12月15日 (月) 晴、時々雨、※欄外に「別府」と書き込みあり。

清風荘(別府)の一室で七時に目がさめる。三人(福田、青木、田郷)一緒に例に より温泉につかる。とても気持がよい。朝食後、宿を出る。八時四十五分別府発 門司行の汽車に乗る。二等車は幸ひにすいてるる。青木さんは公用のため中津で 降りるので、そこで別れる。

門司駅には青木さんの手配どほり、満鉄門司鮮満支案内所の若い人が迎へに出 てみてくれたが、急行券、寝台券は下関のビューローで受取ることになってる るとかで、その人が一緒に来て案内してくれる。ところが、十二時五十分の急行 に乗るには五分の時間しかない。さんざんあわてて、やっと間に合ひ、ほッと 安堵の胸を撫でおろす。この道は東京に通ず。そんな気持がする。

東京に帰るには、この汽車が一番らくである。夜まで何とか時間をつぶし、 寝台に眠机ばもう朝には東京に着くから ‥

夕食後、一酒類は七時からだから、○またまた食堂に入り、福田君と二人、 前の席にるる二八の青年からビール二本を回してもらひ、三本を無邪気に平げて 寝台車の人となる。

○○12月16日(火) 晴、※欄外に「別府一閒司一下関一車中泊」と書き込みあり。 二等寝台車の中で目がさめる。三時。それから二時間ばかりしてまた眠る。 今度は福君に起されて何時ごろ目をさます。窓をある目の真前に富士山がくっき りと全形をあらはしてるる。二人、子供のやうに大よろこびする。朝の新聞が 見たくて、うづうづしてるるが、どこの駅でも売切れてない。食堂に行き朝 食。昨夜ビールを譲ってくれた青年と挨拶をする。食後ヒゲを剃ったり、無駄話 
をしたり、また食堂へ茶を飲みに行ったりしてるるうちに、○○いか時間が 経ってまもなく品川着。帰途は実にらくな旅であった。福田君と明日を約して品 川で別れる。大井町駅に登美子が迎へに来てるた。つれ立って帰る。軽く一本つ けて、二時間ばかりぐっすり眠る。

夜は青木源之助氏その他に手紙を書く。花月劇場で「お祖母さんの分数」をや るらしいが、招待券も来なければ、上演料も来ないので、山嵪醇之輔氏宛に厳重 な抗議状を書く。

戦時議会(臨時)本日より開かる。

12月17日 (水) 晴

「明朗大陸」の原稿を書く。時間が来たので中止して、満鉄東京支社に出かけ る。福田君は既に来てるる。粕谷氏はるなかったが、近藤君に挨拶し、「明朗大 陸」と農山漁村文化協会とに電話をかけて、前者は原稿の延期方を乞ひ後者は明日 まで待ってもらふことにする。福田君とうちつれて、銀座に出、コロンバンの 裏手の大和田で「うなぎ」を食べる。コロンバンでお茶を飲んで福田君と別れ る。宣戦布告後の銀座には始予て出て来たわけだが、天気のせるもあるだらう が、何となく明るい。コロンバンでお年玉にするグライダーの模型、紀伊國屋 で自分のためのポケット日記、新橋の紙屋でお年玉のレターセットなど買ふ。 明治製菓にコーヒーを飲みによると、大森君(改造)があたので、しばらく話す。 徵用された文人の噂など聞く。

夜、酒一合を飲んで眠る。

戦時議会本日終了。

12月18日 (木) 晴

実によい天気だ。但、夜中の二時に目がさめてどうしてもあと眠れず、更に 酒を飲んで寝たものだから、こちらの頭はいさ>モーローとしてるる。

篠原君からお伺ひすべきだが、どうしても都合がつかないから、出版届、契 約書、企画届持参の上、印税をとりに来てもらへまいかとの速達が来たので、出 かけて行き七百五十円の小切手を受取る。篠原君と新潟行の打合せをし、小切手 を第百銀行で現金に換へ五反田の安田に少し貯金をして帰る。

山㠃醇之輔君より「マコトニスミマセン、ケフウカガヒマス、イサイソノト キニ」といふ至急電報が来てるた。

午後六時、山㠃君と吉本の制作部主任の岩本正雄氏来り、事情を述べ、こちら の要求どほり手つぶきを了して落着。 
塙氏に浦敬一顕彰碑の寄付金拾円を送る。

12月19日 (金)

記載なし。

12月20日(土)

記載なし ※全面が翌1942年12月21日の補遺欄として使われている。

12月21日 (日) ※欄外に「越後湯沢」の書き込みあり。

午前十時五十五分上野発新潟行の汽車に乗る。篠原雅之君も同行。

越後路に入ると、もう雪が積ってるる。

午後四時すぎ、目的地の越後湯沢に着く。山間の淋しい温泉場だ。これでも スキーの季節には、大変なお客だといふ。

客引に誘はれるま〉に小泉旅館といふのに泊る。駅から二十分もか>る山の ふもとの古い宿だ。しかし、却ってさびた味があるといってよい。さっそく温 泉につかる。武雄と同じやうに大変めるい。ゆっくりとつかって、部屋でコタ ツに入って二人で酒を飲む。篠原君のためにお配を呼ぶと、野良からそのま〉 出て来たやうな女が二人やって来た。とても篠原君の相手は出来さうもないの で別室に床をとらせ、一人さきに眠る。

夜どほし雪どけの音がする。

12月22日（月）量、※欄外に「水上」と書き込みあり。

昼頃まで小泉旅館に居り、昼食後、○宿を出る。

水上下車。古家ホテルといふのに投宿。こ〉は湯沢と違って、すっかり都会 風の温泉ホテル。しかし、奧利根の清流に望んだ中々よいの温泉である。

朝が遅いといふので、一時五十五分の終列車で立うことにし、それまで遊ぶ ことにする。こ>でも篠原君の相手は宿のものに委して、自分だけ一睡する。

十二時頃、篠原君と二人ッきりでお湯につかり、宵のうちに会計はすまして みたので、寝しづまってるる宿を出る。

○12月23日(火) 晴

大宮で朝の弁当と新聞を買子。

六時、上野駅につく。そこで篠原君と別れて、家に帰る。一睡して、軍人会 館の「少国民文化協会」の総会(発会式)に出席。散会後、産業組合中央会館におけ る農懇の総会に出席。その後で、園池、大島の両氏と木挽町の三笠で夕食。

少し風邪の気味。

12月24日(水) 晴

文学者愛国大会に出席。 
午後一時より、

大政翼賛会大協議室にて

会の後、全員に宮城前まで行進し、聖○の万歳を唱え奉る。

福田清人君とコロンバンでお茶を飲んで別れる。

久しぶりに家で夕飯をとる。

12月25日 (木) 晴

令女界の小説を書き上げる予定だったが、うまく行かず、洋子京子と羽根な どついて時間を䛊間化す。

12月26日 (金) 雨

令女界の小説を書く。が、未完成のま〉家を出る。くろか称会の平出大佐講 演を聞くため。

飯倉一丁目の郵便局で松久君に原稿は明日持参する旨の電報を打つ。

平出大佐の講演の後、昼食。その後また古橋中佐の話を聞く。

以上、水交社。

張赫宙君と銀座に出て、しばらくコロンバンで語る。

12月27日（土）晴

やっと「黒竜江で」十八枚を書き上げて令女界にとぶけに行く。北村君と 始予てゆっくり話す。

実業之日本社に吉田広告部長を訪ね、「南方の詩」の広告につき相談する。そ こを出ると、ちゃうど私を尋㐨てるる中山利国氏に逢ふ。明石鉄也君に「新女苑」 の広告がうまく行ったことを速達し、中山氏と久しぶりにブラジレロで語り、 ビールを一ぱいづつ飲んで帰る。

宮下、安藤両氏来り、安藤氏持参の酒を飲む。

「亜細亜の柱」本日発売。

12月28日(日) 晴

「日本の娘」の書直しにか>る。

夜、和田さんちに招かれて登美子とともに行き、隣組長の相談をうける。

12月29日（月）晴

「日本の娘」ほとんど終日つぶける。

みんなは家の大掃除。

夕食一終日執筆で疲れてしまったので、酒を飲む。早く眠って十一時には目 がさめてしまふ。もう一度酒を飲んで眠る。 
12月30日 (火) 晴、寒い

昨の夜、不確な睡眠しかとらなかったせみか、今日は「日本の娘」も殆ど身が 入らず、のらりくらりと一日をつぶす。

夜、誓君が来たので、頭を刈ってもらひ二人で一杯やる。

12月31日 (水) 快晴、寒冷

博文館から海洋少年文学選の印税(五八. 三四)送って来る。

朝、机のまはりの整理をしただけで今日も朝から「日本の娘」にか〉り昼食ま で、ずっとつぶける。昨日にききかへ今日は成績がよい。

昨年から正月の用意は登美子や洋子京子に委せることにしたが、今年は更に 徹底的に委せてしまふ。

午後、奉天の北尾さんに年末年始の挨拶と、カレンダーのお礼を書いて出 于。

おやつに年越しそば(天プラそばと、うどん)を食べる。洋子、京子とお湯に 行く。去年と同じにお祝儀二円を包む。

午後五時、洋子京子をつれて明治神宮に詣でる。但、燈管のために一の鳥居 までしか参拝出来ない。帰途、五反田の白木屋に寄って、遊び道具や、経子ちゃ んへのお年玉など買ふ。家に帰ったのは八時近く、それから神仏にお酒を供 へ、夕食にする。一合余りを飲んで早目に眠る。

以下、補遺欄につぶく

(※以下、巻末の1941年分の補遺欄)

○十二月三十日の補遺

日本が実力をもって世界史に登場した年として、紀元二千六百一年は日本人に とっては勿論のこと、世界の人に永久に記憶されるであらう。国家的にも世界的 にも左程重大な年であった今年は、私個人にとっても四十一年の 000 今日ま での生涯の中では最も忘机難い年であった。殆ど七、八年も仕事らしい仕事を残 して来なかった私は今年も亦、作品の上では残すべき何程の仕事もしてるな い。けれども、来るべき年にこそ、愈々作品の上に私の人生を築かなければな らぬ最後の段階へ立到った年が今年である。さういふ意味で唯もう忙しいばか りで仕事らしい仕事をしなかった年ではあるが、今更それを悔ひることはすま い。昨年は物質的に何の苦もなく年を送った最初の年として、年末は心愉しかっ たが、今年は去年同様、金銭上の悩みはなかったにも拘はらず、去年程、心のど かでないのは、作品が出来なかったからではあるが、しかし、今年といふ年は 私にとって決して無䭾ではなかった。気持よく、この年を送らう! 